\title{
Alpha Radiolysis of Sorbed Water on Uranium Oxides and Uranium Oxyfluorides
}

September 2003

Prepared by

A. S. Icenhour

L. M. Toth 


\title{
DOCUMENT AVAILABILITY
}

Reports produced after January 1, 1996, are generally available free via the U.S. Department of Energy (DOE) Information Bridge:

Web site: http://www.osti.gov/bridge

Reports produced before January 1, 1996, may be purchased by members of the public from the following source:

\author{
National Technical Information Service \\ 5285 Port Royal Road \\ Springfield, VA 22161 \\ Telephone: 703-605-6000 (1-800-553-6847) \\ TDD: 703-487-4639 \\ Fax: 703-605-6900 \\ E-mail: info@ntis.fedworld.gov \\ Web site: http://www.ntis.gov/support/ordernowabout.htm
}

Reports are available to DOE employees, DOE contractors, Energy Technology Data Exchange (ETDE) representatives, and International Nuclear Information System (INIS) representatives from the following source:

Office of Scientific and Technical Information

P.O. Box 62

Oak Ridge, TN 37831

Telephone: 865-576-8401

Fax: 865-576-5728

E-mail: reports@adonis.osti.gov

Web site: http://www.osti.gov/contact.html

This report was prepared as an account of work sponsored by an agency of the United States Government. Neither the United States government nor any agency thereof, nor any of their employees, makes any warranty, express or implied, or assumes any legal liability or responsibility for the accuracy, completeness, or usefulness of any information, apparatus, product, or process disclosed, or represents that its use would not infringe privately owned rights. Reference herein to any specific commercial product, process, or service by trade name, trademark, manufacturer, or otherwise, does not necessarily constitute or imply its endorsement, recommendation, or favoring by the United States Government or any agency thereof. The views and opinions of authors expressed herein do not necessarily state or reflect those of the United States Government or any agency thereof. 
ORNL/TM-2003/172

\section{ALPHA RADIOLYSIS OF SORBED WATER ON URANIUM OXIDES AND URANIUM OXYFLUORIDES}

A. S. Icenhour

L. M. Toth

Date Published: September 2003

Prepared by

OAK RIDGE NATIONAL LABORATORY

P.O. Box 2008

Oak Ridge, Tennessee 37831-6283

managed by

UT-Battelle, LLC

for the

U.S. DEPARTMENT OF ENERGY

under contract DE-AC05-00OR22725 



\section{CONTENTS}

Page

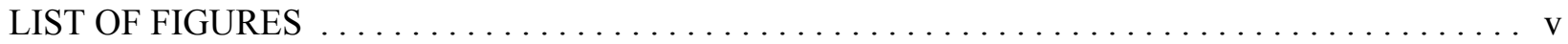

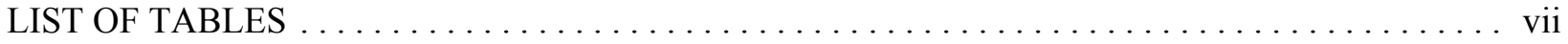

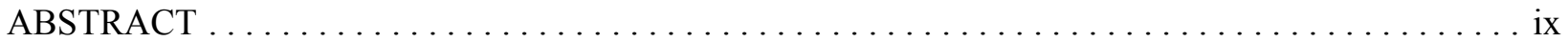

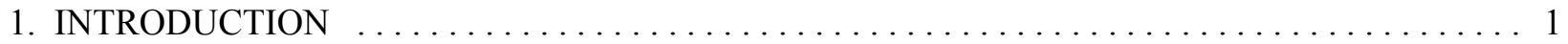

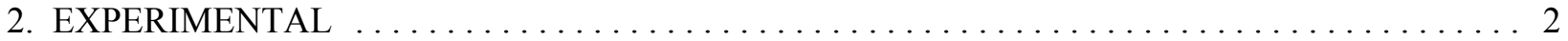

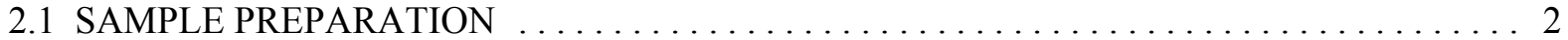

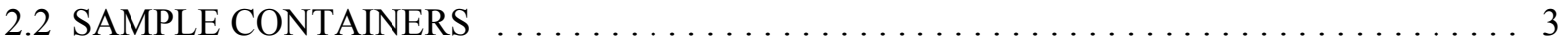

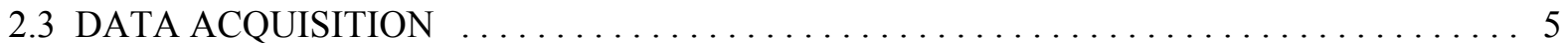

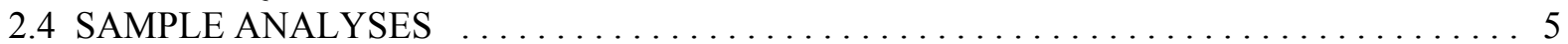

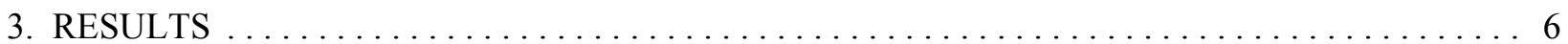

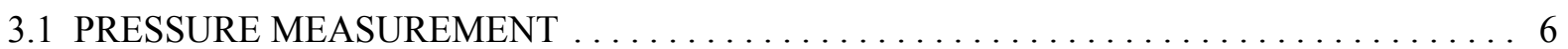

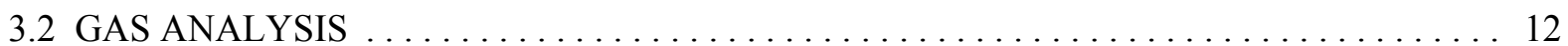

3.3 X-RAY DIFFRACTION RESULTS FOR $\mathrm{U}_{3} \mathrm{O}_{8} \mathrm{AND} \mathrm{UO}_{3} \ldots \ldots \ldots \ldots \ldots \ldots \ldots \ldots \ldots$

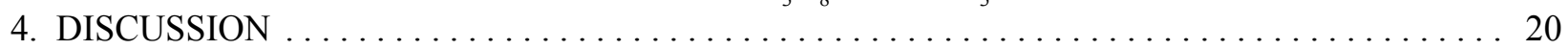

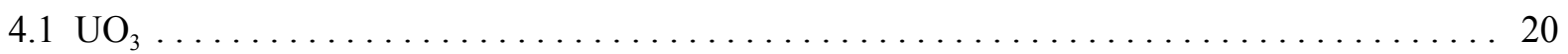

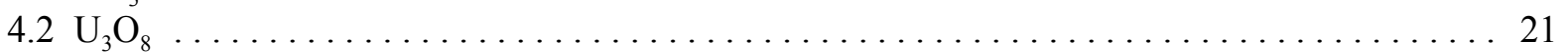

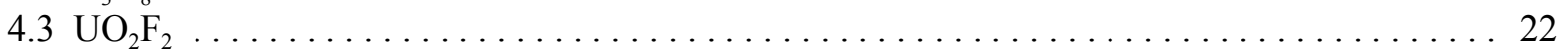

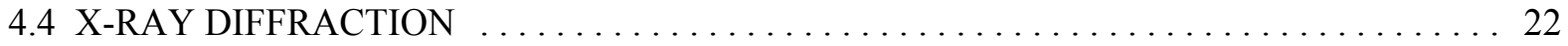

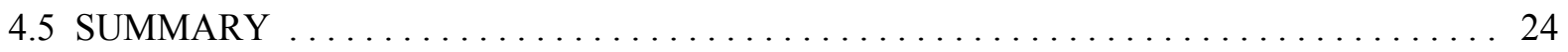

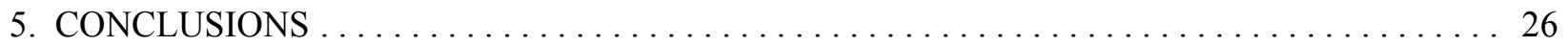

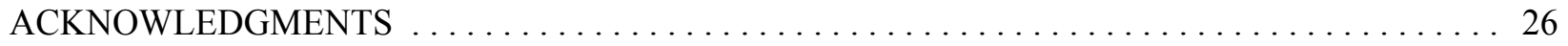

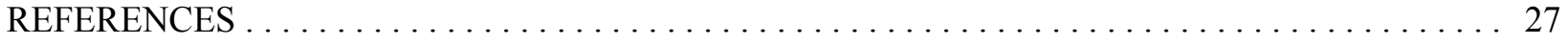





\section{LIST OF FIGURES}

Figure

Page

2.1 Comparison of alpha dose as a function of time for a $\mathrm{U}_{3} \mathrm{O}_{8}$ sample that consists of ${ }^{238} \mathrm{U}$ spiked with about $4400 \mathrm{ppm}{ }^{244} \mathrm{Cm}$ and one that consists of ${ }^{233} \mathrm{U}$ containing about $160 \mathrm{ppm}{ }^{232} \mathrm{U} . \ldots \ldots \ldots \ldots \ldots \ldots \ldots \ldots \ldots \ldots \ldots \ldots \ldots \ldots \ldots$

2.2 Sample container and pressure transducer configuration used in the

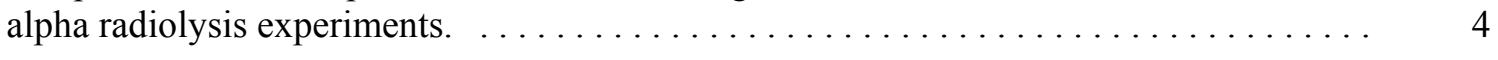

2.3 Photograph of data acquisition system and glove box used for the experiments. . . . . 5

3.1 Pressure and gas yield as a function of dose for sample A-1 $\left(\mathrm{UO}_{3}\right.$ spiked with $\left.{ }^{244} \mathrm{Cm}\right) \ldots \quad 7$

3.2 Pressure and gas yield as a function of dose for sample A-2-1

$\left(\mathrm{UO}_{3}+10 \mathrm{wt} \% \mathrm{H}_{2} \mathrm{O}\right.$, spiked with $\left.{ }^{244} \mathrm{Cm}\right) . \ldots \ldots \ldots \ldots \ldots \ldots \ldots \ldots \ldots \ldots \ldots \ldots \ldots \ldots \ldots \ldots \ldots \ldots$

3.3 Pressure and gas yield as a function of dose for sample A-2-2 $\left(\mathrm{UO}_{3}+10\right.$ wt $\% \mathrm{H}_{2} \mathrm{O}$, spiked with ${ }^{244} \mathrm{Cm}$ and followed by additional rinsing with $\mathrm{NH}_{4} \mathrm{OH}$ to remove nitrates) $\ldots \ldots \ldots \ldots \ldots \ldots \ldots \ldots \ldots \ldots \ldots \ldots \ldots \ldots \ldots \ldots$

3.4 Pressure and gas yield as a function of dose for sample A-3 $\left(\mathrm{U}_{3} \mathrm{O}_{8}\right.$ spiked with $\left.{ }^{244} \mathrm{Cm}\right) . \ldots \quad 9$

3.5 Pressure and gas yield as a function of dose for sample A-4-1 $\left(\mathrm{U}_{3} \mathrm{O}_{8}\right.$ with

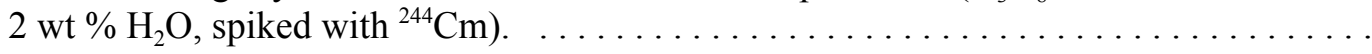

3.6 Pressure and gas yield as a function of dose for sample A-5

$\left(\mathrm{UO}_{2} \mathrm{~F}_{2}\right.$ wetted with ${ }^{244} \mathrm{Cm}$ solution and then dried $) . . \ldots \ldots \ldots \ldots \ldots \ldots \ldots \ldots \ldots \ldots \ldots$

3.7 Pressure and gas yield as a function of dose for sample A-6

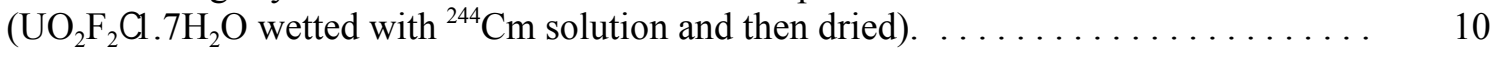

3.8 Calibration and rinse data for additional rinsing during preparation of A-2-2 $\ldots \ldots \ldots 11$ 



\section{LIST OF TABLES}

Table

Page

2.1 Example of radionuclide composition and dose contribution data for material

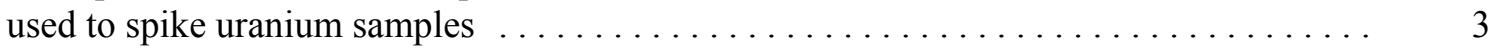

2.2 Void volume of sample containers $\ldots \ldots \ldots \ldots \ldots \ldots \ldots \ldots \ldots \ldots \ldots \ldots$

3.1 Summary of irradiation experiments performed $\ldots \ldots \ldots \ldots \ldots \ldots \ldots \ldots \ldots \ldots$

3.2 Results of mass spectrometric analysis (volume percentage) of gas composition

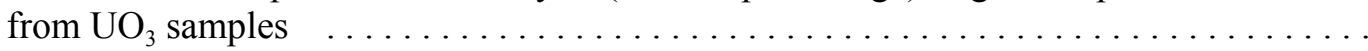

3.3 Results of mass spectrometric analysis (volume percentage) of gas composition

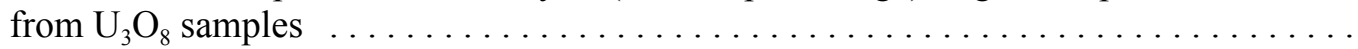

3.4 Results of mass spectrometric analysis (volume percentage) of gas composition

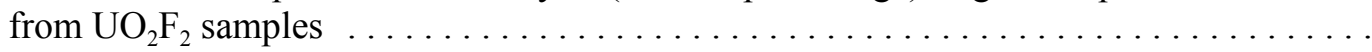

3.5 Comparison of gas composition (relative to argon) for a standard air composition

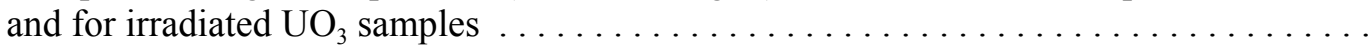

3.6 Comparison of gas composition (relative to argon) for a standard air composition

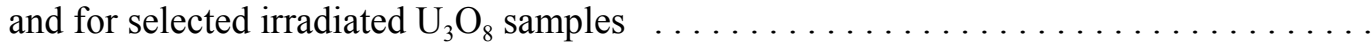

3.7 Comparison of gas composition (relative to argon) for a standard air composition

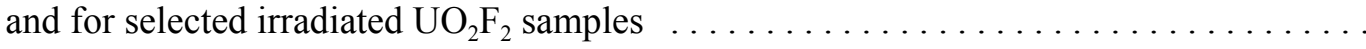

3.8 Estimated change in gas composition for selected experiments as a result of radiolysis

Estimate of hydrogen production as a percentage of moisture on sample $\ldots \ldots \ldots \ldots$

3.10 Estimated mole percentage of uranium oxidized by oxygen consumption . . . . . . . 19

$3.11 \quad$ X-ray diffraction data for uranium oxides $\ldots \ldots \ldots \ldots \ldots \ldots \ldots \ldots \ldots \ldots \ldots$ 



\begin{abstract}
The radiolysis of sorbed water and other impurities contained in actinide oxides has been the focus of a number of studies related to the establishment of criteria for the safe storage and transport of these materials. Gamma radiolysis studies have previously been performed on uranium oxides and oxyfluorides $\left(\mathrm{UO}_{3}, \mathrm{U}_{3} \mathrm{O}_{8}\right.$, and $\left.\mathrm{UO}_{2} \mathrm{~F}_{2}\right)$ to evaluate the long-term storage characteristics of ${ }^{233} \mathrm{U}$. This report describes a similar study for alpha radiolysis.

Uranium oxides and oxyfluorides (with ${ }^{238} \mathrm{U}$ as the surrogate for ${ }^{233} \mathrm{U}$ ) were subjected to relatively high alpha radiation doses (235 to $634 \mathrm{MGy}$ ) by doping with ${ }^{244} \mathrm{Cm}$. The typical irradiation time for these samples was about 1.5 years, which would be equivalent to more than 50 years irradiation by a ${ }^{233} \mathrm{U}$ sample. Both dry and wet (up to $10 \mathrm{wt} \%$ water) samples were examined in an effort to identify the gas pressure and composition changes that occurred as a result of radiolysis.

This study shows that several competing reactions occur during radiolysis, with the net effect that only very low pressures of hydrogen, nitrogen, and carbon dioxide are generated from the water, nitrate, and carbon impurities, respectively, associated with the oxides. In the absence of nitrate impurities, no pressures greater than 1000 torr are generated. Usually, however, the oxygen in the air atmosphere over the oxides is consumed with the corresponding oxidation of the uranium oxide. In the presence of up to $10 \mathrm{wt} \%$ water, the oxides first show a small pressure rise followed by a net decrease due to the oxygen consumption and the attainment of a steady-state pressure where the rate of generation of gaseous components is balanced by their recombination and/or consumption in the oxide phase.

These results clearly demonstrate that alpha radiolysis of either wet or dry ${ }^{233} \mathrm{U}$ oxides will not produce deleterious pressures or gaseous components that could compromise the long-term storage of these materials.
\end{abstract}





\section{INTRODUCTION}

The radiolysis of sorbed water and other impurities contained in actinide oxides has been the focus of a number of studies that centered on the establishment of criteria for the safe storage and transport of the oxides. These criteria are designed to prevent the production of large pressures or hazardous products (e.g., hydrogen and fluorine) that could be deleterious to storage containers and that might result in the release of radioactivity. Storage standards have been developed for both plutonium and uranium to address these concerns. ${ }^{1,2}$ In support of the development of these standards, a number of radiolysis studies have been performed to evaluate the yields of radiolytic products (e.g., Refs. 3-8).

Uranium-233, which is stored primarily at Oak Ridge National Laboratory (ORNL), contains a contaminant isotope, ${ }^{232} \mathrm{U}$, which has a daughter isotope, ${ }^{208} \mathrm{Tl}$, that emits a 2.6-MeV gamma ray. Hence, these materials have a relatively high alpha activity as well as a large gamma radiation field, both of which complicate their handling. Experimental studies have been conducted on the gamma radiolysis of sorbed water on uranium oxides and on fluoride impurities in these oxides (primarily on uranium oxyfluorides)..$^{3-5}$ These experiments have demonstrated that, with respect to gamma radiation, these materials can be safely stored. To complete the understanding of radiolysis in a ${ }^{233} \mathrm{U}$ oxide system, a similar set of experiments have been pursued to explore the effects of alpha radiolysis. In all of these experiments, ${ }^{238} \mathrm{U}$ was used as a surrogate for the ${ }^{233} \mathrm{U} /{ }^{232} \mathrm{U}$, with radiation supplied from a separate source. A surrogate alpha emitter, ${ }^{244} \mathrm{Cm}$, was used in place of the ${ }^{233} \mathrm{U} /{ }^{232} \mathrm{U}$. The use of the surrogate alpha source offers the advantages of (1) a higher specific alpha activity, which provides for an accelerated experiment, and (2) the elimination of the use of ${ }^{233} U /{ }^{232} U$, which results in a significant personnel dose avoidance and more easily handled materials. This report documents the results of the alpha radiolysis experiments that have been performed on uranium oxides and oxyfluorides. 


\section{EXPERIMENTAL}

\subsection{SAMPLE PREPARATION}

The surrogate uranium oxides were prepared by doping natural uranyl nitrate hexahydrate $\left[\mathrm{UO}_{2}\left(\mathrm{NO}_{3}\right)_{2} \mathrm{CGH}_{2} \mathrm{O}\right]$ with the desired amount of curium nitrate $\left(\sim 25 \mathrm{mg}{ }^{244} \mathrm{Cm}\right.$ as a $0.04 M$ solution in $4 \mathrm{~N} \mathrm{HNO}_{3}$ ), coprecipitating the uranium and curium, and then calcining the precipitate. The procedure used was developed by first coprecipitating cerium and uranium. The chemical concentrations, rinsing steps, and calcination temperatures were thereby established.

Use of ${ }^{244} \mathrm{Cm}$ provided a dose rate about 37 times that which would be achieved if the sample was ${ }^{233} \mathrm{U}$ (with $160 \mathrm{ppm}{ }^{232} \mathrm{U}$ ), as shown in Fig. 2.1. An example of the radionuclide composition for the ${ }^{244} \mathrm{Cm}$ solution and dose contribution data is presented in Table 2.1. Note that the ${ }^{244} \mathrm{Cm}$ solution contains a number of radioisotopes, and that while only $50 \mathrm{wt} \%$ of the material is ${ }^{244} \mathrm{Cm}$, more than $99 \%$ of the dose is attributed to the ${ }^{244} \mathrm{Cm}$.

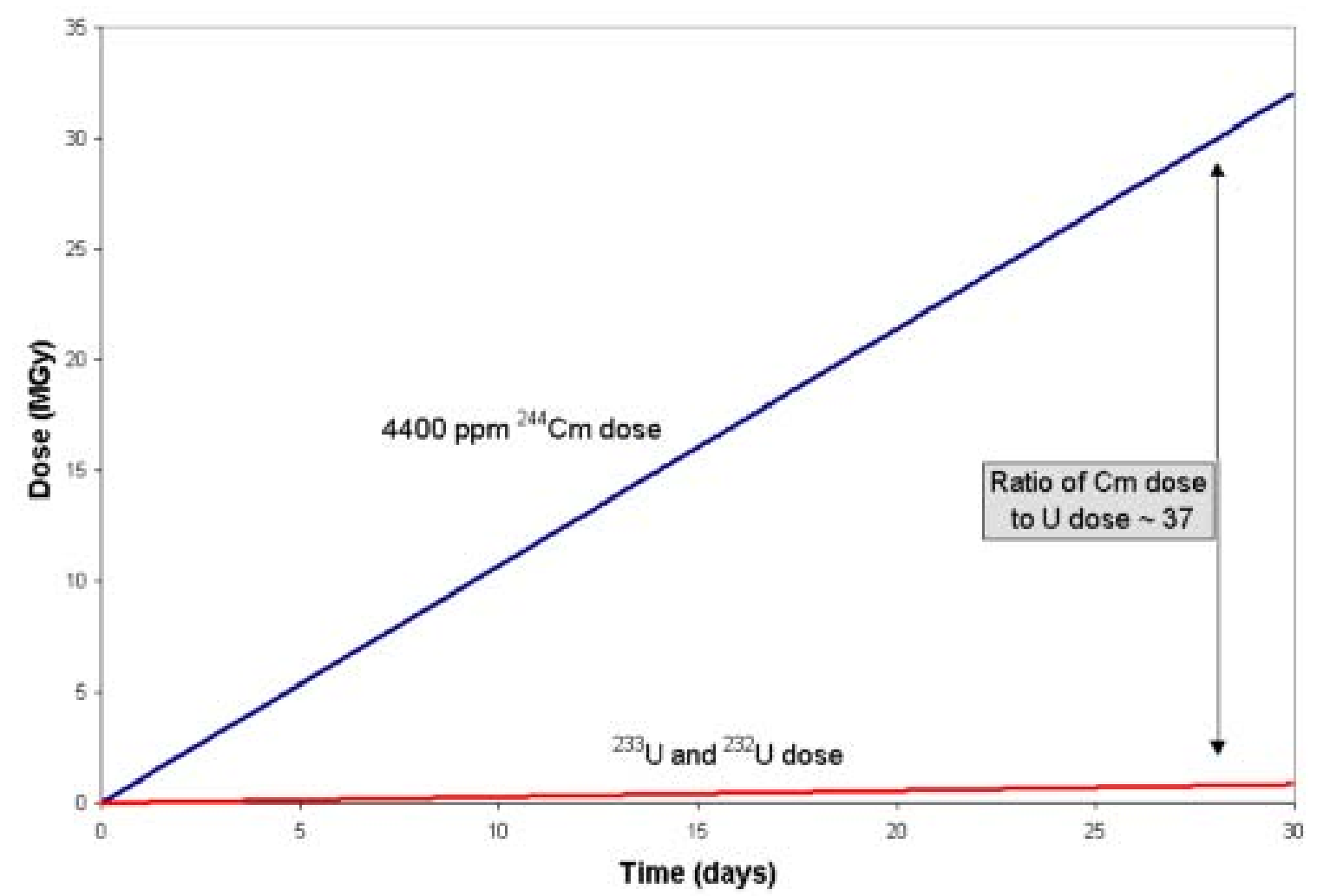

Fig 2.1. Comparison of alpha dose as a function of time for a $\mathrm{U}_{3} \mathrm{O}_{8}$ sample that consists of ${ }^{238} \mathrm{U}$ spiked with about $4400 \mathrm{ppm}{ }^{244} \mathrm{Cm}$ and one that consists of ${ }^{233} \mathrm{U}$ containing about $160 \mathrm{ppm}{ }^{232} \mathrm{U}$. 
Table 2.1. Example of radionuclide composition and dose contribution data for material used to spike uranium samples

\begin{tabular}{clcccc}
\hline Radionuclide & $\begin{array}{c}\text { Half-life } \\
\text { (years) }\end{array}$ & $\begin{array}{c}\text { Specific activity } \\
(\mathrm{Ci} / \mathrm{g})\end{array}$ & $\begin{array}{c}\text { Average alpha } \\
\text { energy }(\mathrm{MeV})\end{array}$ & $\begin{array}{c}\text { Composition } \\
(\text { wt \%) }\end{array}$ & $\begin{array}{c}\text { Contribution } \\
\text { to dose (\%) }\end{array}$ \\
\hline${ }^{244} \mathrm{Cm}$ & 18.11 & 80.9 & 5.7965 & 50.34 & 99.74 \\
${ }^{245} \mathrm{Cm}$ & 8500 & 0.1717 & 5.363 & 1.36 & 0.01 \\
${ }^{246} \mathrm{Cm}$ & 4730 & 0.3072 & 5.376 & 7.31 & 0.05 \\
${ }^{247} \mathrm{Cm}$ & $1.56 \times 10^{7}$ & $9.20 \times 10^{5}$ & 4.9475 & 0.12 & $<<0.01$ \\
${ }^{248} \mathrm{Cm}$ & $3.40 \times 10^{5}$ & 0.00424 & 4.6524 & 0.07 & $<<0.01$ \\
${ }^{240} \mathrm{Pu}$ & 6563 & 0.22696 & 5.1549 & 40.04 & 0.20 \\
${ }^{241} \mathrm{Pu}$ & 14.4 & 103 & 0.000118 & $<<0.01$ & $<<0.01$ \\
${ }^{242} \mathrm{Pu}$ & $3.76 \times 10^{5}$ & 0.003926 & 4.89 & $<<0.01$ & $<<0.01$ \\
${ }^{243} \mathrm{Am}$ & 7380 & 0.1993 & 5.2656 & 0.76 & $<<0.01$ \\
\hline
\end{tabular}

The uranium and curium solutions were mixed and were then coprecipitated as a hydroxide in quartz tubes using concentrated ammonium hydroxide $\left(\mathrm{NH}_{4} \mathrm{OH}\right)$. The precipitate was centrifuged and rinsed with $\mathrm{NH}_{4} \mathrm{OH}$. The precipitate was subsequently heated overnight to the appropriate temperature to obtain the desired oxide (about $350^{\circ} \mathrm{C}$ for $\mathrm{UO}_{3}$ and about $650^{\circ} \mathrm{C}$ for $\mathrm{U}_{3} \mathrm{O}_{8}$ ). Uranyl fluoride samples could not be prepared by this method, because the $\mathrm{UO}_{2} \mathrm{~F}_{2}$ could not be formed as a precipitate. Instead, $\mathrm{UO}_{2} \mathrm{~F}_{2}$ was wetted with a curium nitrate solution and then dried overnight at $350^{\circ} \mathrm{C}$. This temperature was selected to be sufficiently high to decompose the nitrate but low enough to prevent disproportionation of the $\mathrm{UO}_{2} \mathrm{~F}_{2}$. The samples were loaded into instrumented containers. Just prior to closure of the sample containers, the desired amount of water was added to each sample using a calibrated pipette.

\subsection{SAMPLE CONTAINERS}

The samples were placed in stainless steel containers, which were connected by a small-diameter stainless steel tube to a pressure transducer and to a valve (Fig. 2.2). These containers were constructed from a $1 / 2$-in. Cajon VCR socket-weld gland that had a short piece of $1 / 2$-in. tubing welded to it. The tubing was closed at one end with an 1/8-in.-thick disk. The overall length of the container was about 3.5 in. The container was closed with a VCR cap that was drilled through and had 1/16-in. tubing connected to it. The tubing led to a tee that was connected to a pressure transducer and a Nupro valve, 
which was used for leak testing and withdrawal of gas samples. Filter gaskets ( $0.5-\mu \mathrm{m}$ sintered frit) were used in the VCR face-sealed connections to prevent movement of particles and the spread of contamination. The void volume of the containers was measured by expanding helium from a known volume, and the measured volumes are shown in Table 2.2. Samples were prepared and loaded into the containers in a glove box at the ORNL Radiochemical Engineering Development Center.

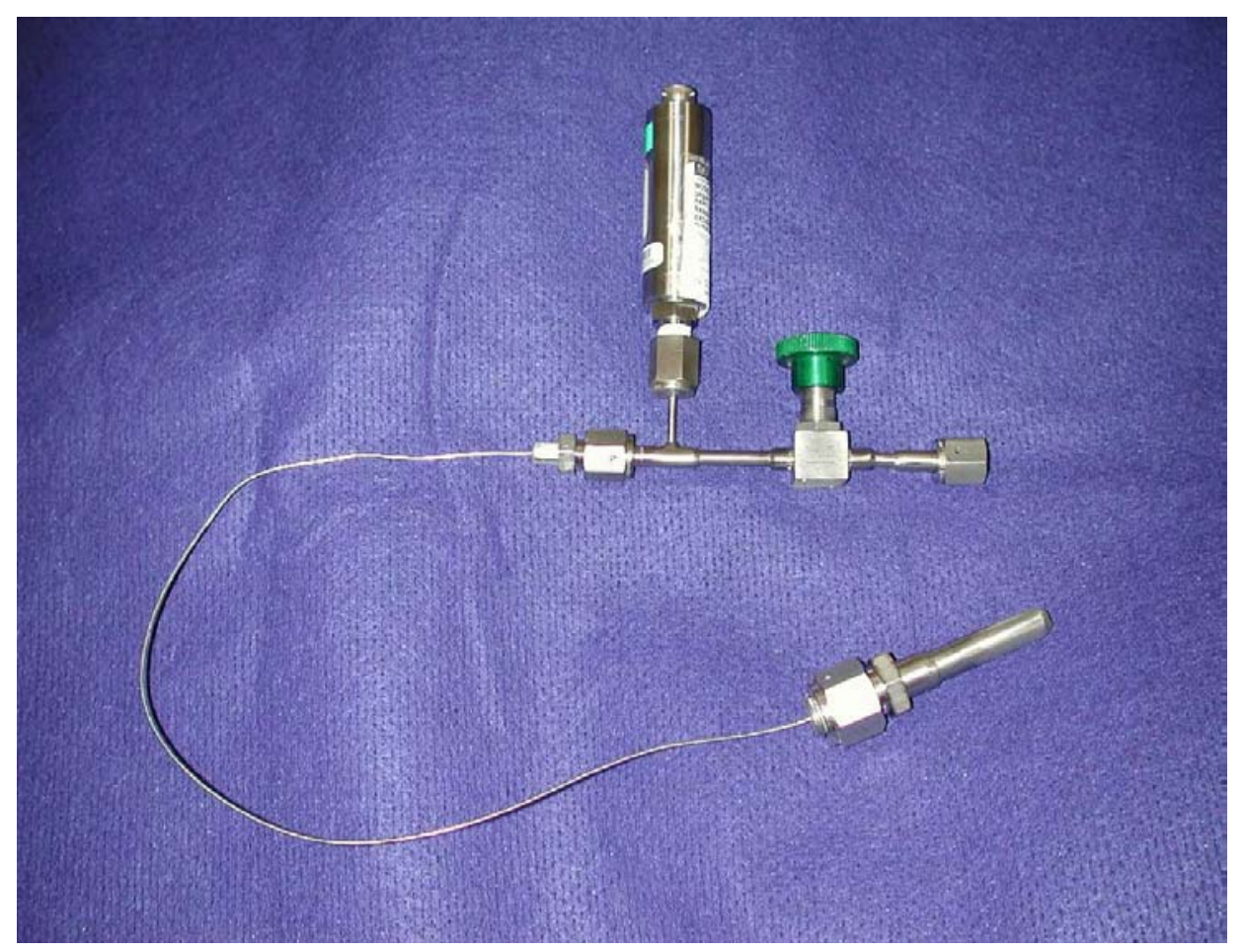

Fig. 2.2. Sample container and pressure transducer configuration used in the alpha radiolysis experiments.

Table 2.2 Void volume of sample containers

\begin{tabular}{cc}
\hline Container & Volume $\left(\mathrm{cm}^{3}\right)$ \\
\hline A-1 & 12.6 \\
A-2-1, A-2-2 & 12.9 \\
A-3 & 12.7 \\
A-4-1 & 12.4 \\
A-5 & 12.7 \\
A-6 & 12.3 \\
\hline
\end{tabular}




\subsection{DATA ACQUISITION}

A computerized data acquisition system was used to record the pressure in the sample containers throughout the irradiations (Fig. 2.3). Validyne ${ }^{\circledR}$ hardware and software were used, providing up to eight data channels per card. Sensotec ${ }^{\circledR}$ pressure transducers (Model FPA) were used to measure the pressure. An Omega ${ }^{\circledR}$ Type $\mathrm{K}$ thermocouple was placed in contact with the exterior of one of the sample containers to obtain a representative temperature for each of the containers.

\subsection{SAMPLE ANALYSES}

During the irradiations, gas samples were periodically withdrawn and analyzed by mass spectrometry. Some samples were analyzed by X-ray diffraction (XRD) by loading capillaries with a small amount of ground sample and running XRD on a Debye-Scherrer camera using MoKa radiation. This very classic method for XRD analysis greatly minimized the amount of sample required and satisfied ALARA (as low as reasonably achievable) requirements for radiation exposure. During the preparation of one of the $\mathrm{UO}_{3}$ samples, nitrate analyses were performed using a nitrate-specific electrode because it was suspected that radiolysis of residual nitrates contributed to an observed pressure increase.

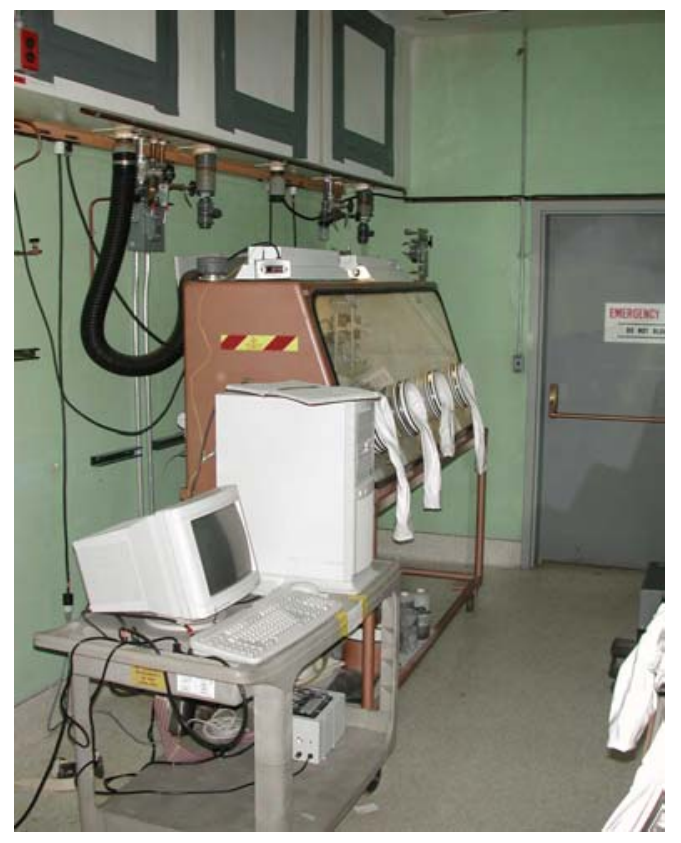

Fig. 2.3. Photograph of data acquisition system and glove box used for the experiments. 


\section{RESULTS}

The effects of alpha particle irradiation on the various wet and dry uranium oxide/oxyfluoride samples were studied by monitoring the pressure changes of the gas atmosphere in contact with them throughout the irradiation period followed by gas composition analyses of samples taken both on occasion during the experiment and at the end of the irradiation. Finally, XRD measurements were made on some of the oxides before and after irradiation to determine if any changes in the crystalline phases had occurred as a result of the alpha radiation exposure to the atmospheres in which they were in contact.

\subsection{PRESSURE MEASUREMENT}

Table 3.1 provides a summary of the irradiation experiments performed. Most of these samples were irradiated for more than 1.5 years with these relatively intense internal sources. The pressure data from each of the experiments are shown in Figs. 3.1-3.7 as gas yield (millimoles of gas per gram of sample) versus calculated dose. The gas yield was calculated using the ideal gas law. The dose to the sample was calculated based on the amount of ${ }^{244} \mathrm{Cm}$ present in the sample, assuming that all of the decay energy from the ${ }^{244} \mathrm{Cm}$ was deposited in the sample (i.e., in the uranium oxide or oxyfluoride plus the added $\mathrm{H}_{2} \mathrm{O}$ ).

Even after very long periods of alpha radiolysis, the pressures were generally observed to reach a limit ("plateau" or "steady-state" value) that is much lower than the net pressure expected from the radiolytic conversion of all the moisture to hydrogen and oxygen. These plateaus are usually preceded by some fluctuations that depend on the presence of water on the sample. Typical for the samples containing moisture is the appearance of a pressure rise that peaks and then proceeds downward to a steady-state value - one that is either slightly larger or smaller that the starting pressure of the system.

For dry $\mathrm{UO}_{3}$ (Fig. 3.1), a slight decrease in pressure is followed by a steady growth to steady-state value of approximately 1000 torr. However, for a wetted $\mathrm{UO}_{3}$ sample (Figs. 3.2 and 3.3), an initial rise is followed by a decrease in pressure to a steady-state value. Dry $\mathrm{U}_{3} \mathrm{O}_{8}$ and $\mathrm{UO}_{2} \mathrm{~F}_{2}$ samples show only a progressive decrease to the limiting steady-state value, while the respective wetted samples show some increase in pressure, which is then followed by a decrease to a subatmospheric pressure. 
Table 3.1. Summary of irradiation experiments performed

\begin{tabular}{llccc}
\hline Experiment & Material & ${\text { Mass }(\mathrm{g})^{a}}^{244} \mathrm{Cm}$ added $(\mathrm{mg})$ & Total dose (MGy) \\
\hline A-1 & $\mathrm{UO}_{3}$ & 6.21 & 24.9 & 595 \\
A-2-1 & $\mathrm{UO}_{3}+10 \mathrm{wt} \% \mathrm{H}_{2} \mathrm{O}$ & 5.90 & 25.0 & 329 \\
A-2-2 & $\mathrm{UO}_{3}+10 \mathrm{wt} \% \mathrm{H}_{2} \mathrm{O}^{b}$ & 5.86 & 24.9 & 235 \\
A-3 & $\mathrm{U}_{3} \mathrm{O}_{8}$ & 5.60 & 24.9 & 415 \\
A-4-1 & $\mathrm{U}_{3} \mathrm{O}_{8}+2 \mathrm{wt} \% \mathrm{H}_{2} \mathrm{O}$ & 5.64 & 24.9 & 406 \\
A-5 & $\mathrm{UO}_{2} \mathrm{~F}_{2}$ & 4.93 & 25.0 & 634 \\
A-6 & $\mathrm{UO}_{2} \mathrm{~F}_{2} \mathrm{O} .7 \mathrm{H}_{2} \mathrm{O}$ & 4.86 & 25.0 & 595 \\
& $\left(9 \mathrm{wt}_{2} \mathrm{H}_{2} \mathrm{O}\right)$ & & \\
\hline
\end{tabular}

${ }^{a}$ Mass of anhydrous material.

${ }^{b}$ Same method as that used for preparation of sample A-2-1, except that additional rinses were performed to reduce residual nitrates.

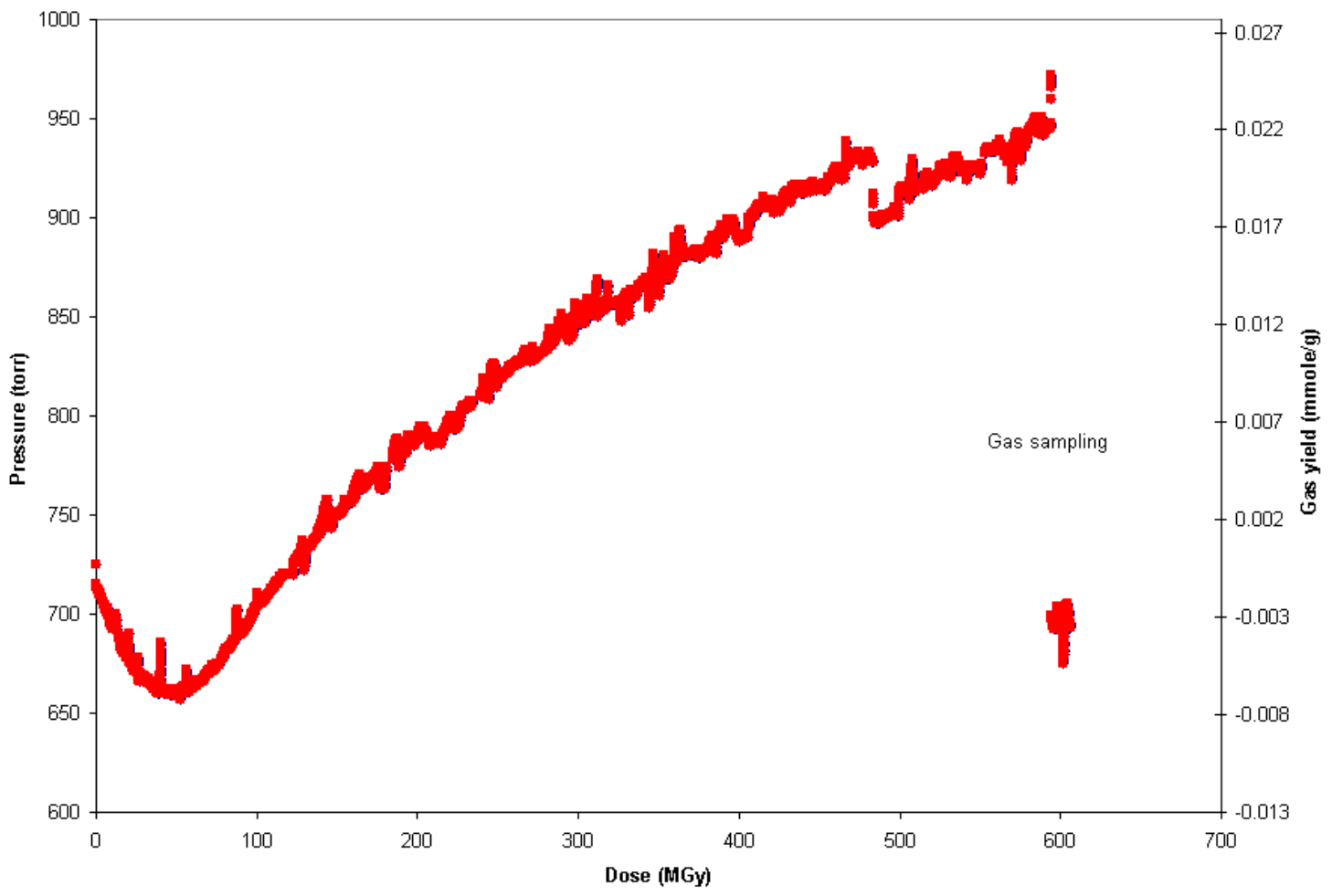

Fig. 3.1. Pressure and gas yield as a function of dose for sample $\mathrm{A}-1\left(\mathrm{UO}_{3}\right.$ spiked with $\left.{ }^{244} \mathrm{Cm}\right)$. 


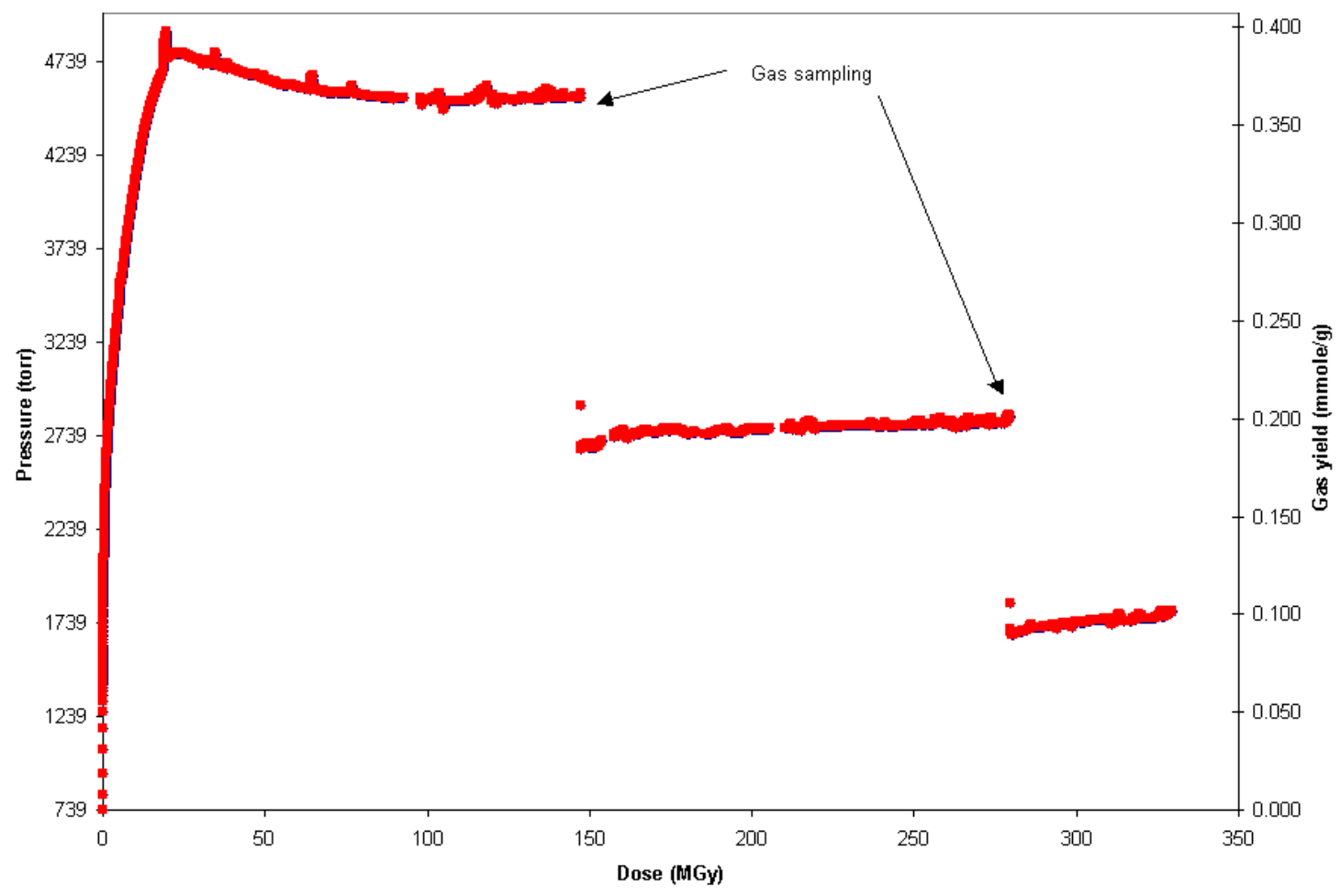

Fig. 3.2. Pressure and gas yield as a function of dose for sample A-2-1 $\left(\mathrm{UO}_{3}+10 \mathrm{wt} \% \mathrm{H}_{2} \mathrm{O}\right.$, spiked with $\left.{ }^{244} \mathrm{Cm}\right)$.

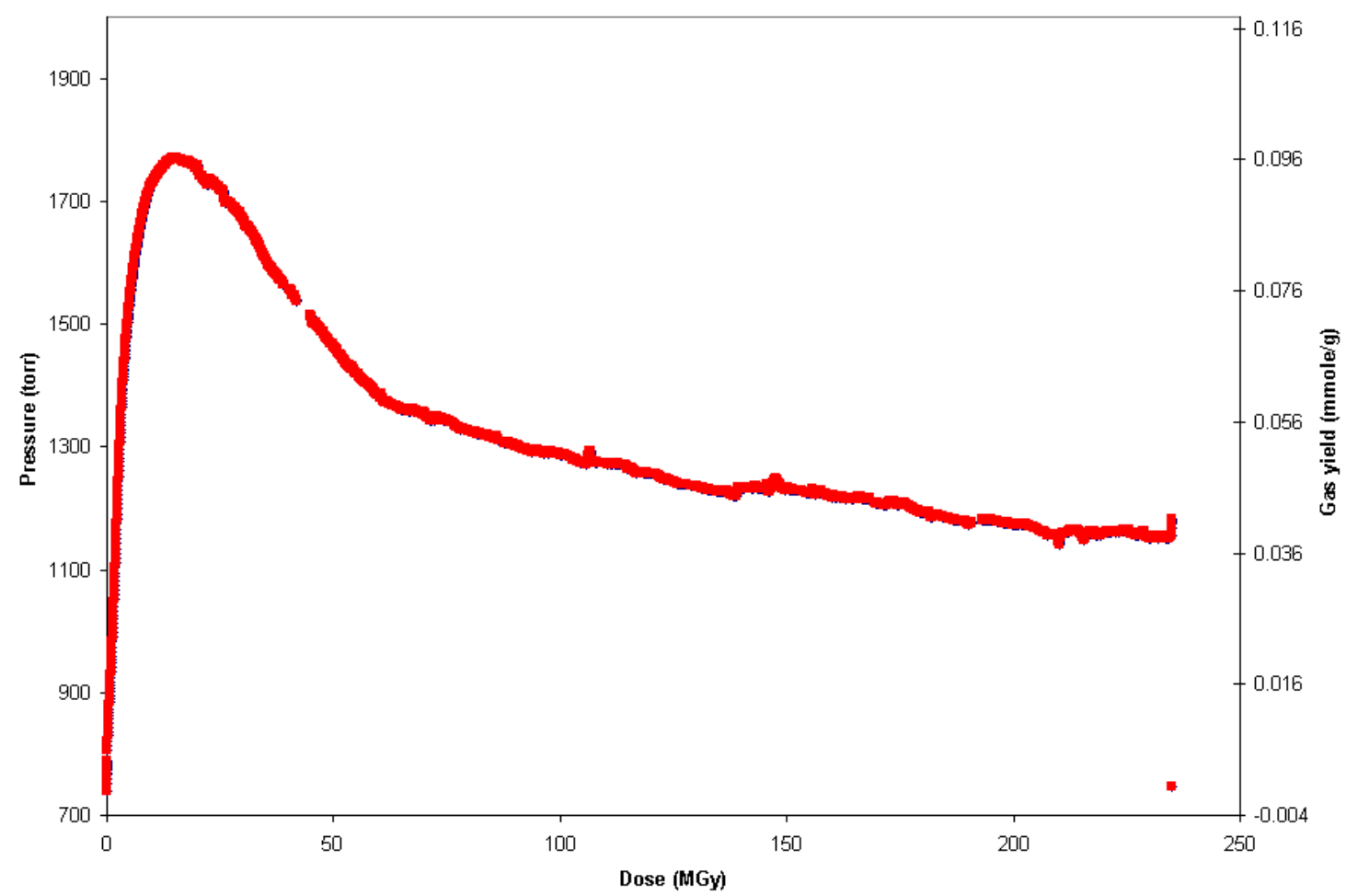

Fig. 3.3. Pressure and gas yield as a function of dose for sample A-2-2 $\left(\mathrm{UO}_{3}+10 \mathrm{wt} \% \mathrm{H}_{2} \mathrm{O}\right.$, spiked with ${ }^{244} \mathrm{Cm}$ and followed by additional rinsing with $\mathrm{NH}_{4} \mathrm{OH}$ to remove nitrates). 


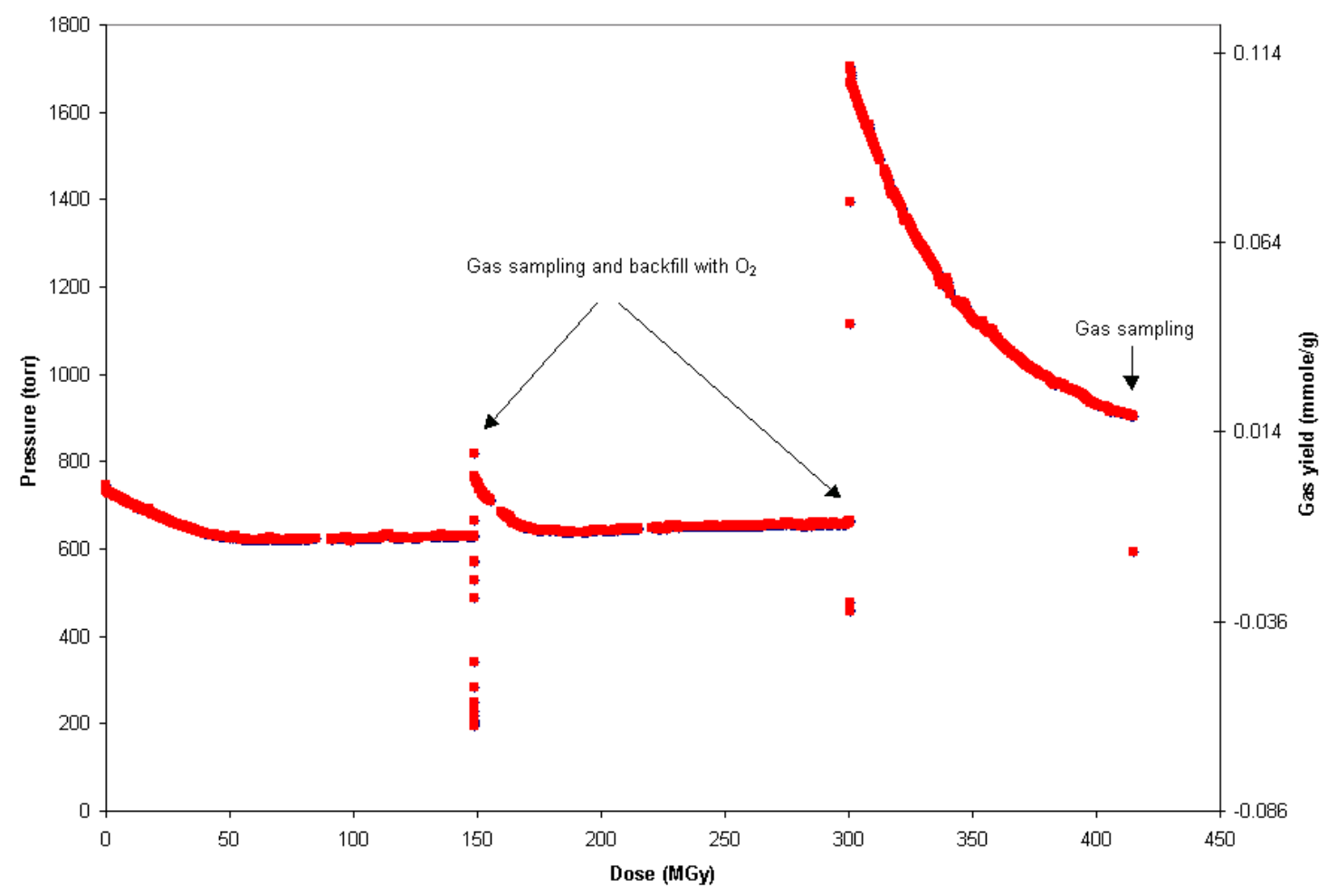

Fig. 3.4. Pressure and gas yield as a function of dose for sample $A-3\left(\mathrm{U}_{3} \mathrm{O}_{8}\right.$ spiked with $\left.{ }^{244} \mathrm{Cm}\right)$.

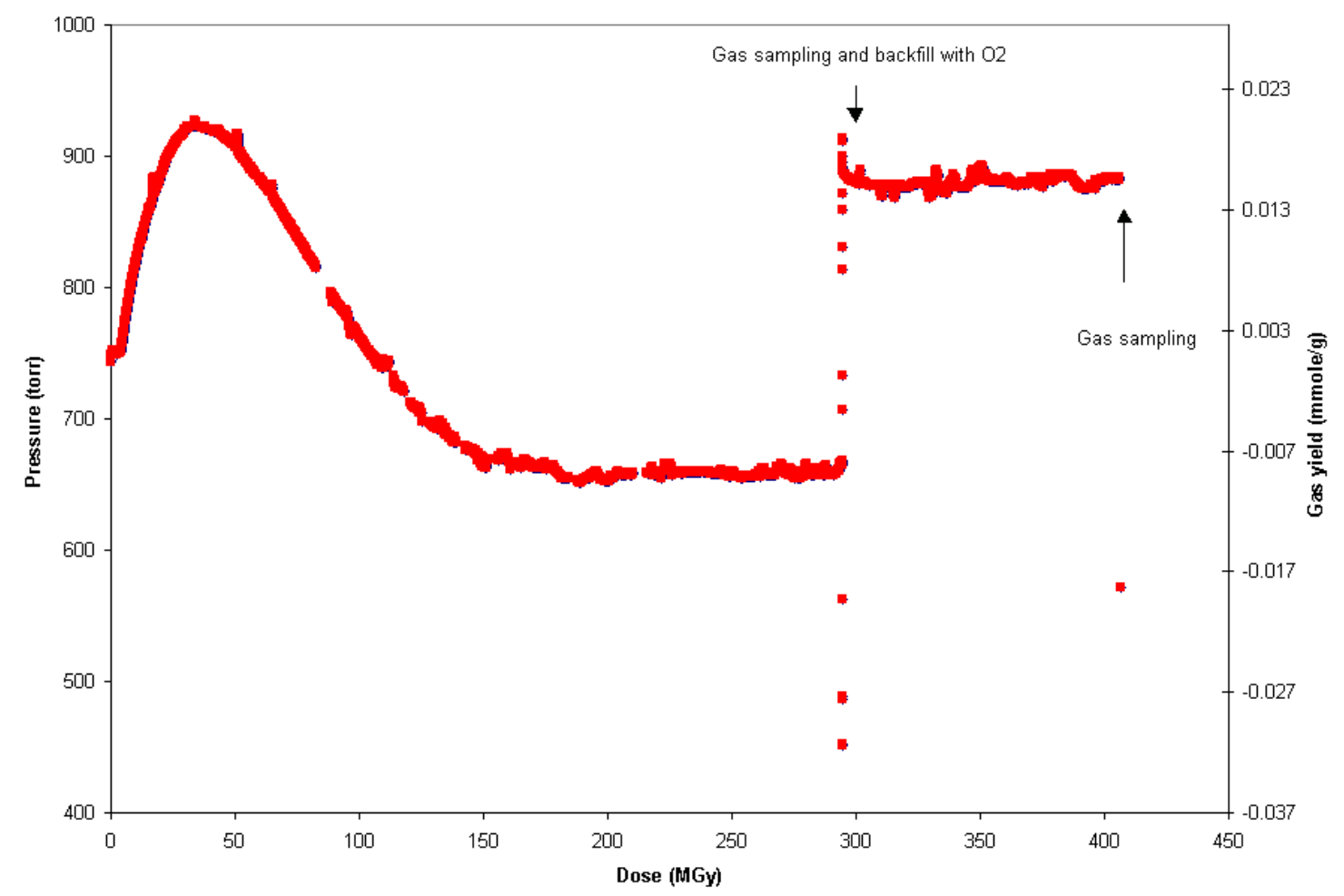

Fig. 3.5. Pressure and gas yield as a function of dose for sample $A-4-1\left(U_{3} O_{8}\right.$ with 2 wt $\% \mathrm{H}_{2} \mathrm{O}$, spiked with ${ }^{244} \mathrm{Cm}$ ). 


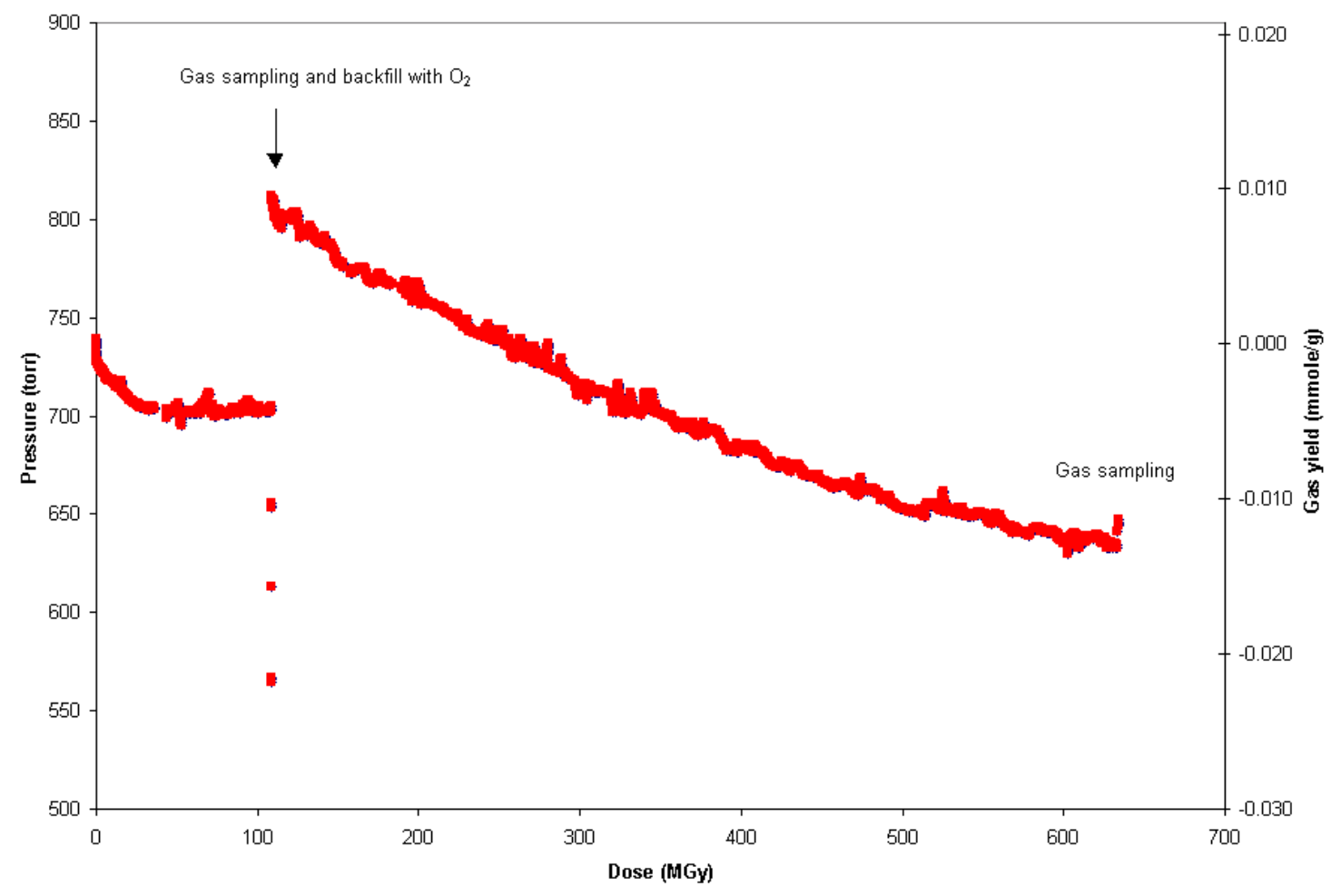

Fig. 3.6. Pressure and gas yield as a function of dose for sample $A-5\left(\mathrm{UO}_{2} \mathrm{~F}_{2}\right.$ wetted with ${ }^{244} \mathrm{Cm}$ solution and then dried).

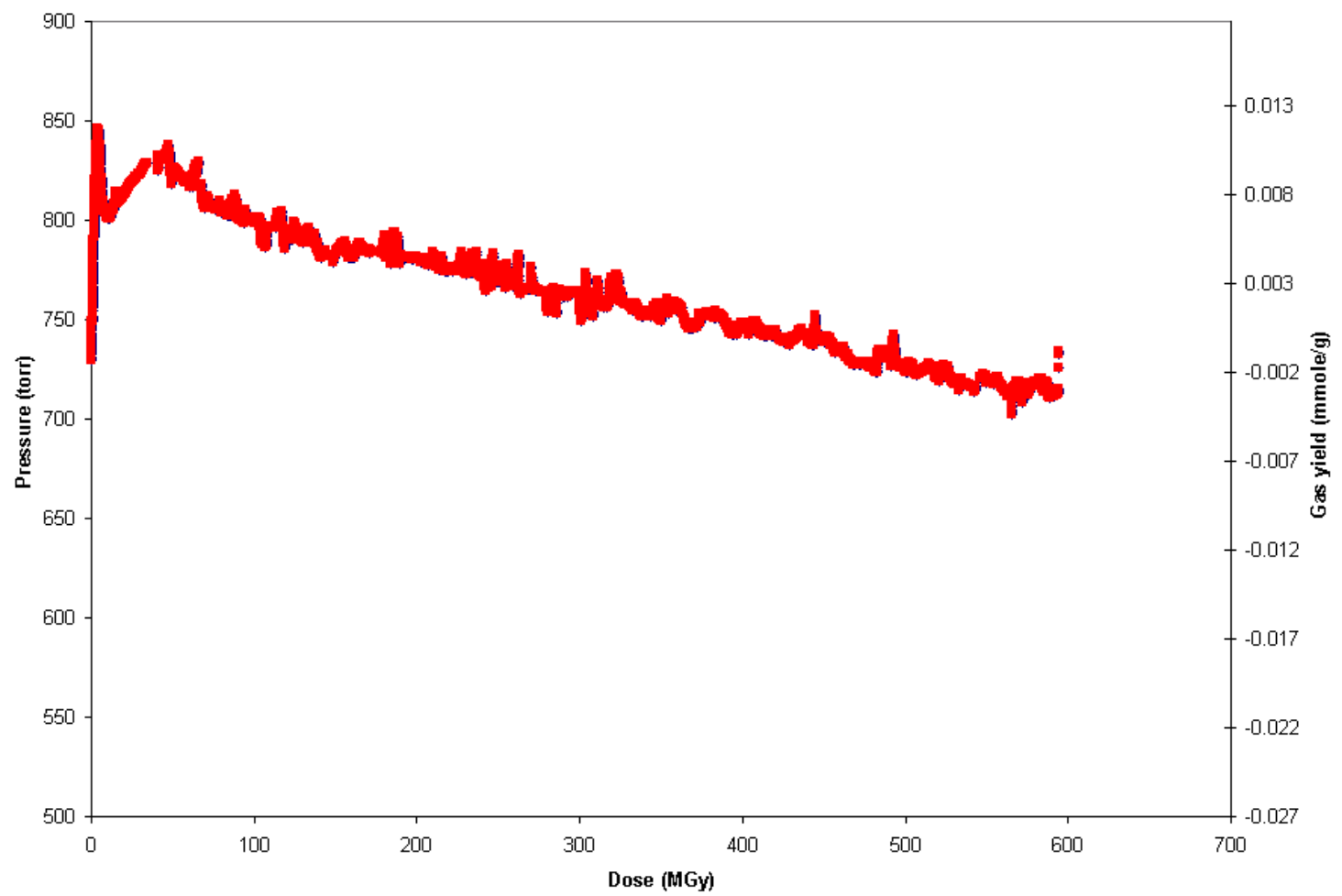

Fig. 3.7. Pressure and gas yield as a function of dose for sample $A-6\left(\mathrm{UO}_{2} \mathrm{~F}_{2} \mathrm{Q} .7 \mathrm{H}_{2} \mathrm{O}\right.$ wetted with ${ }^{244} \mathrm{Cm}$ solution and then dried). 
The only truly anomalous trend was seen with the first wetted $\mathrm{UO}_{3}$ sample, which rapidly reached a relatively high (ultimate) steady-state pressure (Sample A-2-1, Fig. 3.2). Because the gas sample had an unusually high nitrogen content (see next section), it was suspected that the nitrate ion from the reagent material had not been sufficiently washed from the sample and that this residue was radiolyzing in addition to the uranium oxides and moisture.

Therefore, a repeat of this sample preparation and irradiation was deemed necessary but with more thorough washing of the sample after precipitation and separation from the mother liquor. The water from each rinse was monitored with a nitrate-specific ion electrode and compared with a calibration chart for nitrate ion in equivalent ionic strength solutions. ${ }^{*}$ These results are given in Fig. 3.8, which shows that the nitrate concentration in the mother liquor was $\sim 4.2 \mathrm{M}$ and, after 5 rinses, was reduced to $\sim 0.07 \mathrm{M}$ in the final rinse. (Note that in the preparation of sample A-2-1, only one rinse was performed. Based on Fig. 3.8, this process would result in a rinse-solution nitrate concentration of $\sim 1.5 M$, or approximately 20 times that achieved for sample A-2-2.) This material was then dried and run with $10 \%$ added water to give a significantly lower steady-state pressure and an overall profile that better matched the other oxides. [Compare sample A-2-2 (Fig. 3.3) with, for example, sample A-4-1 (Fig. 3.5).]

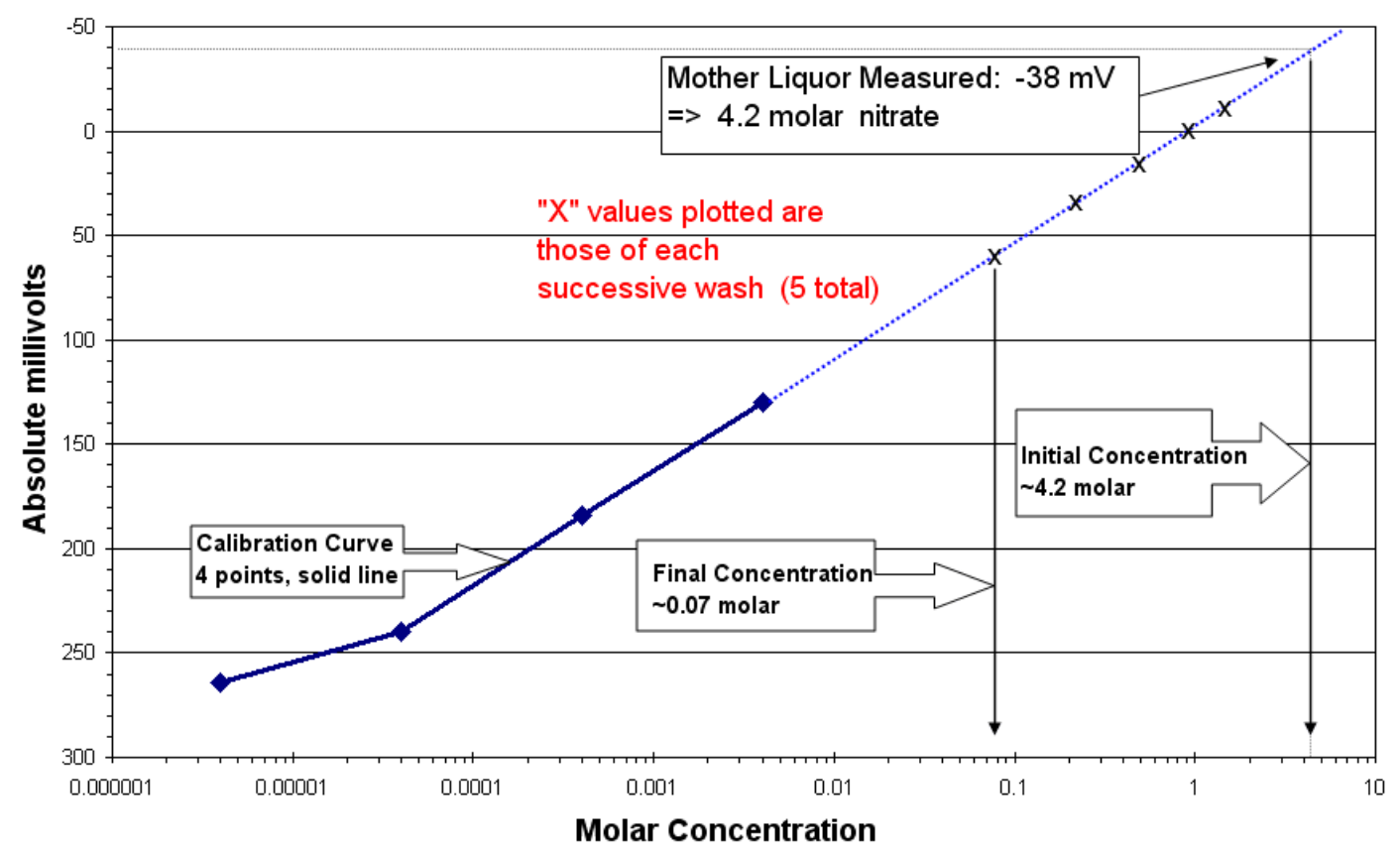

Fig. 3.8. Calibration and rinse data for additional rinsing during preparation of A-2-2.

*The measurement of nitrate ion in the wash solution was easier and less expensive than the more obvious direct destructive analysis of the solid sample. 
The presence of nitrate ion impurity could not be a problem for the $\mathrm{U}_{3} \mathrm{O}_{8}$ and $\mathrm{UO}_{2} \mathrm{~F}_{2}$ samples because these were prepared at temperatures above that at which nitrate decomposes. Furthermore, the gas analyses described in the following section confirm that nitrate ion was not a problem in these other two uranium compounds.

\subsection{GAS ANALYSIS}

Mass spectrometric gas analyses on periodic samples are presented in Tables 3.2-3.4 along with pressure and temperature data at the time of the sampling. The values labeled as "initial" are those at the beginning of the experiment or, in the case of multiple gas samples, the value just after sampling. The "final" values are taken just prior to withdrawal of the gas sample. Hence, these pressure values give a measure of the change during the period prior to sampling.

Table 3.2. Results of mass spectrometric analysis (volume percentage) of gas composition from $\mathrm{UO}_{3}$ samples

\begin{tabular}{|c|c|c|c|c|}
\hline & \multirow{2}{*}{$\begin{array}{c}\mathrm{A}-1 \\
\left(\mathrm{UO}_{3} \text { dry }\right)\end{array}$} & \multicolumn{2}{|c|}{$\begin{array}{c}\mathrm{A}-2-1 \\
\left(\mathrm{UO}_{3} \text { with } 10 \mathrm{wt} \% \mathrm{H}_{2} \mathrm{O}\right) \\
\end{array}$} & \multirow{2}{*}{$\begin{array}{c}\mathrm{A}-2-2 \\
\left(\mathrm{UO}_{3} \text { with } 10 \text { wt } \% \mathrm{H}_{2} \mathrm{O}\right)\end{array}$} \\
\hline & & First gas sample & Second gas sample & \\
\hline Initial atmosphere & Air & Air & Modified air ${ }^{a}$ & Air \\
\hline Initial pressure $^{b}$ (torr) & 725 & 739 & 2671 & 740 \\
\hline Initial temperature ${ }^{c}\left({ }^{\circ} \mathrm{C}\right)$ & 27 & 29 & 25 & 29 \\
\hline Final pressure $^{c}$ (torr) & 972 & 4572 & 2843 & 1183 \\
\hline Final temperature ${ }^{c}\left({ }^{\circ} \mathrm{C}\right)$ & 29 & 25 & 27 & 29 \\
\hline $\mathrm{CO}_{2}$ & 0.01 & 0.03 & 0.01 & 0.02 \\
\hline $\mathrm{CO}$ & $<0.01$ & & & $<0.01$ \\
\hline $\mathrm{Ar}$ & 0.3 & 0.08 & 0.09 & 0.2 \\
\hline $\mathrm{O}_{2}$ & 0.92 & 1.32 & 0.6 & 1.01 \\
\hline $\mathrm{N}_{2}$ & 82.8 & 89.2 & 89.09 & 96.68 \\
\hline $\mathrm{NO}_{x}{ }^{d}$ & 0.37 & 0.2 & 0.05 & 0.32 \\
\hline $\mathrm{H}_{2}$ & 0.002 & 0.24 & 0.37 & 0.72 \\
\hline $\mathrm{He}$ & 15.59 & 8.84 & 9.7 & 1.05 \\
\hline
\end{tabular}

${ }^{a}$ Composition remaining after first sample of A-2-1.

${ }^{b}$ Value at beginning of experiment or just after previous gas sampling operation.

${ }^{c}$ Value just prior to withdrawal of gas sample.

${ }^{d}$ Likely in the form $\mathrm{N}_{2} \mathrm{O}$. 
Table 3.3. Results of mass spectrometric analysis (volume percentage) of gas composition from $\mathrm{U}_{3} \mathrm{O}_{8}$ samples

\begin{tabular}{|c|c|c|c|c|c|}
\hline & \multicolumn{3}{|c|}{$\begin{array}{c}\mathrm{A}-3 \\
\left(\mathrm{U}_{3} \mathrm{O}_{8} \text { dry }\right) \\
\end{array}$} & \multicolumn{2}{|c|}{$\begin{array}{c}\mathrm{A}-4-1 \\
\left(\mathrm{U}_{3} \mathrm{O}_{8} \text { with } 2 \text { wt \% } \mathrm{H}_{2} \mathrm{O}\right) \\
\end{array}$} \\
\hline & $\begin{array}{l}\text { First gas } \\
\text { sample }\end{array}$ & $\begin{array}{c}\text { Second gas } \\
\text { sample after } \\
\text { backfill with } \mathrm{O}_{2}\end{array}$ & $\begin{array}{c}\text { Third gas } \\
\text { sample after } \\
\text { backfill with } \mathrm{O}_{2}\end{array}$ & $\begin{array}{l}\text { First gas } \\
\text { sample }\end{array}$ & $\begin{array}{c}\text { Second gas } \\
\text { sample after } \\
\text { backfill with } \mathrm{O}_{2}\end{array}$ \\
\hline Initial atmosphere & Air & Air/additional $\mathrm{O}_{2}{ }^{a}$ & Air/additional $\mathrm{O}_{2}^{b}$ & Air & Air/additional $\mathrm{O}_{2}^{c}$ \\
\hline Initial pressure $^{d}$ (torr) & 744 & 766 & 1701 & 743 & 912 \\
\hline Initial temperature ${ }^{d}\left({ }^{\circ} \mathrm{C}\right)$ & 27 & 24 & 27 & 27 & 27 \\
\hline Final pressure $^{e}$ (torr) & 629 & 663 & 906 & 668 & 883 \\
\hline Final temperature ${ }^{e}\left({ }^{\circ} \mathrm{C}\right)$ & 24 & 27 & 24 & 27 & 25 \\
\hline $\mathrm{CO}_{2}$ & 0.06 & $<.01$ & 0.2 & 0.02 & 0.02 \\
\hline $\mathrm{Ar}$ & 0.8 & 0.4 & 0.43 & 0.7 & 0.29 \\
\hline $\mathrm{O}_{2}$ & 17.29 & 0.7 & 2.23 & 10.06 & 0.88 \\
\hline $\mathrm{N}_{2}$ & 70.1 & 41.24 & 28.06 & 60.17 & 26.17 \\
\hline $\mathrm{NO}_{x}^{f}$ & & 0.23 & 0.11 & 0.03 & 0.024 \\
\hline $\mathrm{H}_{2}$ & 0.001 & 0.01 & 0.003 & 0.44 & 0.97 \\
\hline $\mathrm{H}_{2} \mathrm{O}$ & & & 0.4 & & 0.2 \\
\hline $\mathrm{He}$ & 11.66 & 57.4 & 68.56 & 28.08 & 71.44 \\
\hline $\begin{array}{l}{ }^{a} \text { Composition remaining a } \\
{ }^{b} \text { Composition remaining a } \\
c^{c} \text { Composition remaining a } \\
{ }^{d} \text { Value at beginning of exp } \\
{ }^{C} \text { Value just prior to withdr } \\
\text { Likely in the form } \mathrm{N}_{2} \mathrm{O} .\end{array}$ & $\begin{array}{l}\mathrm{r} \text { first sam } \\
\mathrm{r} \text { second } \mathrm{s} \\
\mathrm{r} \text { first sam } \\
\text { iment or } \mathrm{j} \\
\text { al of gas }\end{array}$ & $\begin{array}{l}\text { le of A-3 plus backf } \\
\text { mple of A-3 plus ba } \\
\text { le of A-4-1 plus bac } \\
\text { st after previous gas } \\
\text { imple. }\end{array}$ & $\begin{array}{l}\text { led with } \mathrm{O}_{2} . \\
\text { sfilled with } \mathrm{O}_{2} \text {. } \\
\text { filled with } \mathrm{O}_{2} \text {. } \\
\text { ampling operation. }\end{array}$ & & \\
\hline
\end{tabular}


Table 3.4. Results of mass spectrometric analysis (volume percentage)

of gas composition from $\mathrm{UO}_{2} \mathrm{~F}_{2}$ samples

\begin{tabular}{|c|c|c|c|}
\hline & \multicolumn{2}{|c|}{$\begin{array}{c}\mathrm{A}-5 \\
\left(\mathrm{UO}_{2} \mathrm{~F}_{2} \text { dry }\right) \\
\end{array}$} & \multirow{2}{*}{$\begin{array}{c}\mathrm{A}-6 \\
\left(\mathrm{UO}_{2} \mathrm{~F}_{2} \mathrm{Q} \cdot 7 \mathrm{H}_{2} \mathrm{O}\right)\end{array}$} \\
\hline & First gas sample & $\begin{array}{l}\text { Second gas sample } \\
\text { after } \mathrm{O}_{2} \text { addition }\end{array}$ & \\
\hline Initial atmosphere & Air & Air/additional $\mathrm{O}_{2}{ }^{a}$ & Air \\
\hline Initial pressure $^{b}$ (torr) & 739 & 811 & 737 \\
\hline Initial temperature ${ }^{b}\left({ }^{\circ} \mathrm{C}\right)$ & 27 & 24 & 27 \\
\hline Final pressure $^{c}$ (torr) & 705 & 646 & 732 \\
\hline Final temperature ${ }^{c}\left({ }^{\circ} \mathrm{C}\right)$ & 24 & 29 & 29 \\
\hline $\mathrm{CO}_{2}$ & 0.1 & 1.2 & 1.86 \\
\hline $\mathrm{CO}$ & & 0.32 & 0.03 \\
\hline $\mathrm{Ar}$ & 0.74 & 0.72 & 0.49 \\
\hline $\mathrm{O}_{2}$ & 16.91 & 5.79 & 6.17 \\
\hline $\mathrm{N}_{2}$ & 64.3 & 79.68 & 50.36 \\
\hline $\mathrm{NO}_{x}^{d}$ & & 0.22 & 1.16 \\
\hline $\mathrm{H}_{2}$ & $<0.001$ & 0.007 & 8.15 \\
\hline $\mathrm{He}$ & 18.05 & 12.06 & 31.78 \\
\hline
\end{tabular}

${ }^{a}$ Composition remaining after first sample of A-5 plus backfilled with $\mathrm{O}_{2}$.

${ }^{b}$ Value at beginning of experiment or just after previous gas sampling operation.

${ }^{c}$ Value just prior to withdrawal of gas sample.

${ }^{d}$ Likely in the form $\mathrm{N}_{2} \mathrm{O}$. 
Results from the mass spectrometric analysis of the $\mathrm{UO}_{3}$ samples are shown in Table 3.2. One gas sample was withdrawn at the end of experiment A-1. By contrast, because of the relatively large pressure rise seen for A-2-1, gas samples were taken at two different times from this container (see Fig. 3.2). A gas sample was withdrawn at the end of experiment A-2-2. The introduced helium seen here in the analysis is an artifact of the sampling method.

For the $\mathrm{U}_{3} \mathrm{O}_{8}$ experiments, a pressure decrease was evident and multiple gas samples were also withdrawn. Results of the mass spectrometric analysis of these samples are presented in Table 3.3. After the first gas sample of experiment A-3, the container was evacuated to about 200 torr and was then backfilled with oxygen to a total pressure of 766 torr. After withdrawal of the second gas sample from experiment A-3, the container pressure was about 458 torr (no further evacuation performed). This container was then backfilled with oxygen to a total pressure of 1701 torr. A similar operation was performed for experiment A-4-1. The pressure in A-4-1 was reduced to 450 torr as a result of withdrawal of the first gas sample. The container was then backfilled with oxygen to a total pressure of 912 torr. Because of the manifold configuration, some helium remained in the system and, as a result, the backfill gas was a mixture of helium and oxygen.

The mass spectrometric results for gas samples for the $\mathrm{UO}_{2} \mathrm{~F}_{2}$ experiments are shown in Table 3.4. Two samples were withdrawn from A-5. After the first sample, the container was evacuated to about 200 torr and backfilled with a helium/oxygen mixture to a total pressure of 811 torr. A gas sample was withdrawn from A-6 at the end of the experiment.

The most significant general observation is that the hydrogen content of these gas samples is extremely low. It exceeds $1 \%$ of the total gas sample composition only in sample A-6. However, more careful evaluation of the mass spectrometric data is necessary in order to see the subtle trends that occur during the course of the radiolysis - as described in the following paragraph.

Some insight into the radiolytic effects on the samples can be gained by normalizing the measured gas composition with an inert component of the air, namely argon, that acts as an internal standard. This comparison for the $\mathrm{UO}_{3}$ samples is shown in Table 3.5. Comparisons for selected $\mathrm{U}_{3} \mathrm{O}_{8}$ and $\mathrm{UO}_{2} \mathrm{~F}_{2}$ samples are presented in Tables 3.6 and 3.7, respectively. Selected comparisons were made for these samples because, after initial gas withdrawal, the containers were evacuated and backfilled with oxygen. Table 3.8 presents the estimated change in gas composition (i.e., moles of oxygen and hydrogen formed or consumed) for selected experiments. ${ }^{*}$ The standard air composition ${ }^{9}$ was the assumed starting composition for each experiment.

*Because of the residual helium in the gas manifold, the exact composition of the gas resulting from the oxygen backfilling operation was not known. Consequently, estimates of changes in gas composition could not be made for containers that were backfilled with oxygen. 
Table 3.5. Comparison of gas composition (relative to argon) for a standard air composition and for irradiated $\mathrm{UO}_{3}$ samples

\begin{tabular}{lccccc}
\hline & & & \multicolumn{3}{c}{ A-2-1 } \\
\cline { 4 - 5 } Ratio & $\begin{array}{c}\text { Standard air } \\
\text { composition }^{a}\end{array}$ & A-1 & First gas sample & Second gas sample & \multirow{2}{*}{ A-2-2 } \\
\hline $\mathrm{O}_{2}: \mathrm{Ar}$ & 22.47 & 3.07 & 16.5 & 6.6 & 5.1 \\
$\mathrm{CO}_{2}: \mathrm{Ar}$ & 0.03 & 0.03 & 0.38 & 0.11 & 0.1 \\
$\mathrm{~N}_{2}: \mathrm{Ar}$ & 83.98 & 276 & 1115 & 990 & 483 \\
$\mathrm{H}_{2}: \mathrm{Ar}$ & 0.00005 & 0.007 & 3 & 4 & 4 \\
\hline${ }^{a} \mathrm{From}$ & CRC Handbook of Chemistry and Physics, 73rd ed., D. R. Lide, ed., CRC Press, Boca Raton, Florida, \\
1992. & &
\end{tabular}

Table 3.6. Comparison of gas composition (relative to argon) for a standard air composition and for selected irradiated $\mathrm{U}_{3} \mathrm{O}_{8}$ samples

\begin{tabular}{lccc}
\hline Ratio & $\begin{array}{c}\text { Standard air } \\
\text { composition }^{a}\end{array}$ & $\begin{array}{c}\text { A-3 } \\
\text { First gas sample }\end{array}$ & $\begin{array}{c}\text { A-4-1 } \\
\text { First gas sample }\end{array}$ \\
\hline $\mathrm{O}_{2}: \mathrm{Ar}$ & 22.47 & 21.6 & 14.4 \\
$\mathrm{CO}_{2}: \mathrm{Ar}$ & 0.03 & 0.08 & 0.03 \\
$\mathrm{~N}_{2}: \mathrm{Ar}$ & 83.98 & 87.6 & 85.9 \\
$\mathrm{H}_{2}: \mathrm{Ar}$ & 0.00005 & 0.001 & 0.6 \\
\hline
\end{tabular}

${ }^{a}$ From CRC Handbook of Chemistry and Physics, 73rd ed., D. R. Lide, ed., CRC Press, Boca Raton, Florida, 1992.

Table 3.7. Comparison of gas composition (relative to argon) for a standard air composition and for selected irradiated $\mathrm{UO}_{2} \mathrm{~F}_{2}$ samples

\begin{tabular}{lccc}
\hline Ratio & $\begin{array}{c}\text { Standard air } \\
\text { composition }^{a}\end{array}$ & $\begin{array}{c}\text { A-5 } \\
\text { First gas sample }\end{array}$ & A-6 \\
\hline $\mathrm{O}_{2}: \mathrm{Ar}$ & 22.47 & 22.9 & 12.6 \\
$\mathrm{CO}_{2}: \mathrm{Ar}$ & 0.03 & 0.14 & 3.8 \\
$\mathrm{~N}_{2}: \mathrm{Ar}$ & 83.98 & 86.9 & 103 \\
$\mathrm{H}_{2}: \mathrm{Ar}$ & 0.00005 & 0 & 17 \\
\hline
\end{tabular}

${ }^{a}$ From CRC Handbook of Chemistry and Physics, 73rd ed., D. R. Lide, ed., CRC Press, Boca Raton, Florida, 1992. 
Table 3.8. Estimated change in gas composition for selected

experiments as a result of radiolysis

\begin{tabular}{|c|c|c|}
\hline Gas sample & $\Delta \mathrm{O}_{2}(\mathrm{~mol})$ & $\Delta \mathrm{H}_{2}(\mathrm{~mol})$ \\
\hline A-1 & $! 8.83 \times 10^{\text {G }}$ & $1.45 \times 10^{G B}$ \\
\hline $\begin{array}{l}\text { A-2-1 } \\
\text { First gas sample }\end{array}$ & $! 5.34 \times 10^{\mathrm{G}}$ & $7.35 \times 10^{65}$ \\
\hline $\begin{array}{l}\text { A-2-1 } \\
\text { Second gas sample }\end{array}$ & $! 1.22 \times 10^{\mathrm{G}}$ & $2.87 \times 10^{66}$ \\
\hline A-2-2 & $! 8.49 \times 10^{\mathrm{G}}$ & $5.13 \times 10^{66}$ \\
\hline $\begin{array}{l}\text { A-3 } \\
\text { First gas sample }\end{array}$ & $! 2.01 \times 10^{\mathrm{G}}$ & $4.07 \times 10^{\oplus}$ \\
\hline $\begin{array}{l}\text { A-4-1 } \\
\text { First gas sample }\end{array}$ & $! 3.81 \times 10^{\mathrm{G}}$ & $2.57 \times 10^{65}$ \\
\hline $\begin{array}{l}\text { A-5 } \\
\text { First gas sample }\end{array}$ & $! 5.06 \times 10^{66}$ & 0 \\
\hline A-6 & $! 5.26 \times 10^{\text {G }}$ & $5.15 \times 10^{\mathrm{G}}$ \\
\hline
\end{tabular}

For the $\mathrm{UO}_{3}$ samples, the very high nitrogen content is evident by noting their nitrogen:argon ratios for all the samples, especially for sample A-2-1. It is also evident that the carbon dioxide is elevated, along with a slight amount of hydrogen. However, oxygen is depleted from all of these samples. Somewhat similarly, for $\mathrm{U}_{3} \mathrm{O}_{8}$, carbon dioxide is increased (sample A-3) and oxygen is decreased - but both to a lesser degree than in the $\mathrm{UO}_{3}$ samples. Hydrogen is likewise only slightly increased, while there is little change in the nitrogen content (as compared to the $\mathrm{UO}_{3}$ samples). For the $\mathrm{UO}_{2} \mathrm{~F}_{2}$ samples, the only significant observations are increased carbon dioxide for both samples and some hydrogen generation and oxygen depletion for the wet sample, (A-6). Sample A-6 may also indicate a small amount of nitrogen production. The fact that neither HF nor fluorine was found is significant because these corrosive species were a concern for the long-term storage of uranium oxides that contain fluoride impurities. ${ }^{3,5}$

Finally, the hydrogen production for each of the wetted samples is shown in Table 3.9 by estimating the hydrogen production as a mole percentage of the available water. This table shows that only a very small amount of the water was radiolyzed to form hydrogen. 
Table 3.9. Estimate of hydrogen production as a percentage of moisture on sample

\begin{tabular}{lccc}
\hline \multicolumn{1}{c}{ Experiment } & $\begin{array}{c}\text { Initial } \begin{array}{c}\mathrm{H}_{2} \mathrm{O} \text { content } \\
(\mathrm{mol})\end{array} \\
\begin{array}{l}\text { A-2-1 } \\
\text { (after second gas sample) }\end{array}\end{array}$ & $\begin{array}{c}\text { Estimated } \mathrm{H}_{2} \text { production } \\
(\mathrm{mol})\end{array}$ & $\begin{array}{c}\text { Available } \mathrm{H}_{2} \mathrm{O} \text { radiolyzed } \\
(\mathrm{mol} \%)\end{array}$ \\
$\begin{array}{l}\text { A-2-2 } \\
\text { A-4-1 (after first gas }\end{array}$ & 0.033 & $1.02 \times 10^{! 5}$ & 0.03 \\
sample) & 0.0063 & $5.13 \times 10^{! 6}$ & 0.02 \\
A-6 & 0.027 & $2.57 \times 10^{! 6}$ & 0.04 \\
\hline
\end{tabular}

\subsection{X-RAY DIFFRACTION RESULTS FOR $\mathrm{U}_{3} \mathrm{O}_{8}$ AND UO $_{3}$}

XRD measurements were obtained for the uranium oxides before and after the alpha radiolysis experiments to determine if any measurable change in the crystalline form had occurred as a result of the radiolysis. The XRD patterns of the pure materials agreed with those reported in the literature ${ }^{10-12}$ for the $\mathrm{U}_{3} \mathrm{O}_{8}$ and anhydrous $\mathrm{UO}_{3}$ used in these experiments.

Realizing that $5 \%$ or more of a new crystalline phase would typically have to be present in order to be seen by XRD, an estimate of the possible extent of conversion to a new phase was made by noting the consumption of oxygen as measured in the gas analyses. Results of these estimates are presented in Table 3.10. Note that these estimates do not consider the oxidation of uranium directly by the radiolysis products of water. In some cases the estimated oxidation amounted to as much as $6 \%$, thus giving some confidence that a new crystalline phase could, in principle, be detected under these conditions. However, limitations in length of irradiation time and the unavailability of more XRD measurements prevented a complete investigation from being made. Nevertheless, some interesting and supportive observations have resulted from these measurements.

After irradiation, the wetted samples showed a few new lines, notably at Mo $(\lambda=0.70930 \mathrm{D}) 2 \theta$ values of 5.48 and 17.57 for $\mathrm{U}_{3} \mathrm{O}_{8}$ and $6.62,10.72$, and 15.77 for $\mathrm{UO}_{3}$ as shown in Table 3.11. The dry $\mathrm{U}_{3} \mathrm{O}_{8}$ showed weak lines at $2 \theta$ values of 8.03 and 8.73 , while the dry $\mathrm{UO}_{3}$ sample gave no XRD pattern at all. 
Table 3.10. Estimated mole percentage of uranium oxidized by oxygen consumption

\begin{tabular}{lc}
\hline \multicolumn{1}{r}{ Experiment } & ${\text { Mol \% } \mathrm{U}_{\text {oxidized }}{ }^{a}}^{\text {A-1 }}$ \\
A-2-1 & 0.7 \\
A-2-2 & 0.6 \\
A-3 & 0.8 \\
A-4-1 & 6 \\
\hline
\end{tabular}

${ }^{a}$ Does not consider possible oxidation by-products from the radiolysis of water.

Table 3.11. X-ray diffraction data for uranium oxides ${ }^{a}$

\begin{tabular}{|c|c|c|c|}
\hline \multicolumn{2}{|c|}{$\mathrm{U}_{3} \mathrm{O}_{8}$} & \multicolumn{2}{|c|}{$\mathrm{UO}_{3}$} \\
\hline Unirradiated & $\begin{array}{l}\text { A-4-1 after } \\
\text { irradiation }\end{array}$ & Unirradiated & $\begin{array}{l}\text { A-2-2 after } \\
\text { irradiation }\end{array}$ \\
\hline & $5.48 \mathrm{~m}$ & & $6.62 \mathrm{~s}$ \\
\hline $6.57 \mathrm{w}$ & & $8.03 \mathrm{~s}$ & $7.97 \mathrm{~s}$ \\
\hline $9.87 \mathrm{~s}$ & $9.82 \mathrm{~s}$ & $9.33 \mathrm{w}$ & $9.42 \mathrm{w}$ \\
\hline $11.87 \mathrm{~m}$ & $12.02 \mathrm{~s}$ & & $10.72 \mathrm{w}$ \\
\hline $12.57 \mathrm{w}$ & $12.72 \mathrm{~W}$ & $11.58 \mathrm{vs}$ & $11.82 \mathrm{vs}$ \\
\hline \multirow[t]{3}{*}{$15.57 \mathrm{~s}$} & $15.52 \mathrm{~s}$ & $12.48 \mathrm{vw}$ & $12.67 \mathrm{~m}$ \\
\hline & $16.67 \mathrm{vvw}$ & $14.33 \mathrm{~m}$ & $14.12 \mathrm{~m}$ \\
\hline & $17.57 \mathrm{~m}$ & & $15.77 \mathrm{~m}$ \\
\hline $19.77 \mathrm{w}$ & $19.77 \mathrm{w}$ & $16.18 \mathrm{~m}$ & $16.32 \mathrm{~m}$ \\
\hline $20.22 \mathrm{w}$ & $20.22 \mathrm{vw}$ & $19.08 \mathrm{w}$ & $18.87 \mathrm{w}$ \\
\hline $21.15 \mathrm{w}$ & $20.82 \mathrm{w}$ & & $19.72 \mathrm{w}$ \\
\hline $23.12 \mathrm{~s}$ & $23.17 \mathrm{~s}$ & $20.68 \mathrm{~m}$ & $20.57 \mathrm{~m}$ \\
\hline \multirow[t]{2}{*}{$24.07 \mathrm{vw}$} & $23.97 \mathrm{w}$ & $22.03 \mathrm{vw}$ & $22.82 \mathrm{w}$ \\
\hline & $24.92 \mathrm{vw}$ & $23.53 \mathrm{w}$ & $23.72 \mathrm{w}$ \\
\hline \multirow[t]{2}{*}{$25.87 \mathrm{vvw}$} & $25.97 \mathrm{w}$ & & \\
\hline & $26.92 \mathrm{vvw}$ & & \\
\hline \multirow[t]{3}{*}{$28.72 \mathrm{w}$} & $28.87 \mathrm{w}$ & & \\
\hline & $29.77 \mathrm{w}$ & & \\
\hline & $30.52 \mathrm{w}$ & & \\
\hline $31.17 \mathrm{vw}$ & $31.37 \mathrm{vw}$ & & \\
\hline $32.17 \mathrm{w}$ & $32.22 \mathrm{w}$ & & \\
\hline
\end{tabular}

${ }^{a}$ The $2 \theta$ values given are for MoK $\alpha$ radiation; the wavelength is $0.70930 \mathrm{D}$. Intensities are denoted by the following: $\mathrm{s}=$ strong; $\mathrm{m}=$ medium; $\mathrm{w}=$ weak. The addition of the prefix "v" indicates "very." 


\section{DISCUSSION}

In order to assess the effects of long-term self-irradiation by radioactive materials such as ${ }^{232} \mathrm{U} /{ }^{233} \mathrm{U}$ on a time scale that is reasonable in the laboratory, it is necessary to irradiate surrogate samples to equivalent doses but at a necessarily higher dose rate. Considering the higher dose rate supplied by the ${ }^{244} \mathrm{Cm}$, the doses achieved correspond to more than 50 years of irradiation with a ${ }^{233} \mathrm{U} /{ }^{232} \mathrm{U}$ source, thus achieving the desired result of equivalent long-term irradiation exposure.

\section{1 $\mathrm{UO}_{3}$}

Examination of Figs. 3.1-3.3 shows a net pressure increase for each of the samples. This increase is consistent with the presence of trace nitrate ion in the samples that is radiolyzed in addition to the uranium oxide and/or water that might be on the sample. In the case of the anhydrous $\mathrm{UO}_{3}$ sample (A-1, Fig. 3.1), the pressure was seen to initially decrease and then slowly increase. The gas sample taken from A-1 (see Tables 3.2 and 3.5) revealed that nitrogen was produced and oxygen was consumed.

Furthermore, it is apparent that some trace water, either as hydrate or adsorbed moisture, is radiolyzed along with the nitrate impurity, as confirmed by the presence of trace hydrogen in the gas sample.

However, any oxygen produced is also consumed. It appears then that the initial pressure increase is a result of nitrogen generation, while the overall pressure decrease results from oxygen consumption.

A much more dramatic pressure rise was seen for sample A-2-1, which consisted of $\mathrm{UO}_{3}$ with $10 \mathrm{wt} \% \mathrm{H}_{2} \mathrm{O}$ added (Fig. 3.2). For this sample, the pressure quickly rose to about 4750 torr and then slowly decreased as it appears a steady state was approached. After taking two gas samples of A-2-1, which resulted in a net decrease of the system pressure, the pressure appeared to rise very slowly towards a new plateau.

The gas analysis for the samples withdrawn from A-2-1 (Tables 3.2 and 3.5) clearly shows that nitrogen was produced and oxygen consumed. Only a small amount $(<1$ vol \%) of hydrogen was produced. Hence, again it is seen that the initial rise in pressure results from nitrogen production, while the decrease from the peak is probably due to oxygen consumption. Ultimately, this combination of mechanisms approaches a steady-state value.

The results of more thorough rinsing of the sample to remove nitrate ion produced a situation in which much less nitrogen was generated, although such production was not completely eliminated.

Consequently, a much lower overall steady-state pressure was achieved after irradiation of this material. The curve profile for this sample, A-2-2 (Fig. 3.3), is more typical of all the wet uranium oxide samples 
$\left(\mathrm{UO}_{3}, \mathrm{U}_{3} \mathrm{O}_{8}\right.$, and $\left.\mathrm{UO}_{2} \mathrm{~F}_{2}\right)$, where there is an initial rise in pressure followed by a steady decrease to a lower limiting value.

These results are interpreted as the combination of multiple mechanisms taking place in the system. First, water and nitrate are radiolyzed by energy transfer through the uranium/curium oxide lattice to form some oxygen, hydrogen, and nitrogen. The oxygen comes from both nitrate and water radiolysis. These gaseous components would eventually reach a steady state without a peaking and subsequent decrease of the pressure were it not for the advent of yet another mechanism - a process in which one of the components was consumed, namely oxygen. However, this reaction now occurs at a slower rate. This additional chemical mechanism will be described in greater detail following the discussion of the other uranium oxides.

\section{$4.2 \quad \mathrm{U}_{3} \mathrm{O}_{8}$}

Figures 3.4 and 3.5 exhibit an overall pressure decrease with increasing dose. For the dry $\mathrm{U}_{3} \mathrm{O}_{8}$ sample (A-3, Fig. 3.4), the pressure decreases immediately upon initiation of the experiment and reaches a steady-state value. After the first gas sample, container A-3 was backfilled with a mixture of air and helium. The pressure again decreased to a steady-state value. After a second gas sample was withdrawn, container A-3 was once again pressurized - this time to a much higher pressure-with oxygen (and some residual helium). The pressure in A-3 again decreased and was approaching a steady state when a final gas sample was withdrawn and the experiment terminated. The first gas sample for A-3 (Tables 3.3, 3.6, and 3.8) shows slight evidence of oxygen consumption. However, the second and third gas samples from A-3 (Table 3.3) provide clear evidence of oxygen consumption.

The $\mathrm{U}_{3} \mathrm{O}_{8}$ sample that was loaded with $2 \mathrm{wt} \%$ water (A-4-1, Fig. 3.5) exhibited an initial pressure increase to a peak of about 920 torr and then a decrease to a steady-state pressure. A gas sample was withdrawn and the tube was repressurized with an oxygen/helium mixture. The pressure then decreased again to a steady-state value. A final gas sample was withdrawn at the conclusion of the experiment. The gas analysis (Tables 3.3, 3.6, and 3.8) shows that oxygen was depleted while some hydrogen was produced. The estimated hydrogen production at steady state (Table 3.8) cannot account for the entire pressure rise observed. However, it is likely that the rise is the result of the initial radiolysis of water-producing hydrogen and oxygen. Then back reactions (i.e., recombination of hydrogen and oxygen, and the other, slower oxygen consumption mechanism) result in the overall pressure decrease.

The second gas sample for experiment A-4-1 showed that almost all of the oxygen was consumed. Based on the small pressure change after the first gas sample, it is evident that the backfill gas was primarily helium with little oxygen. 
Once again an initial increase in pressure occurs for a wet sample followed by a net pressure decrease and consumption of oxygen. For the corresponding dry sample, there is simply the consumption of oxygen with associated pressure decrease.

\section{$4.3 \mathrm{UO}_{2} \mathrm{~F}_{2}$}

Figure 3.6 shows the pressure response for the alpha radiolysis of anhydrous $\mathrm{UO}_{2} \mathrm{~F}_{2}(\mathrm{~A}-5)$. The pressure decreased to a steady state, at which point a gas sample was taken. The tube was evacuated to about 200 torr and was then backfilled with an oxygen/helium mixture. The pressure then slowly decreased and appears to approach a steady state again. A final gas sample was taken at the termination of experiment A-5. The analysis of the first gas sample from A-5 (Tables 3.4, 3.7, and 3.8) shows that a small amount of oxygen was consumed. The second gas sample (Table 3.4) showed consumption of the added oxygen. Neither HF nor fluorine was reported. Note that production of these corrosive species was a concern for the long-term storage of uranium oxides containing fluoride impurities. ${ }^{3,5}$ The fact that none were found further demonstrates that these concerns were unwarranted.

The pressure response for the alpha radiolysis of $\mathrm{UO}_{2} \mathrm{~F}_{2} \mathrm{Q} .7 \mathrm{H}_{2} \mathrm{O}(\mathrm{A}-6)$ presented in Figure 3.7 again exhibits an initial pressure increase followed by an overall pressure decrease similar to that for the other wet oxides. The gas analysis of the sample taken at the end of the experiment (Tables 3.4, 3.7, and 3.8) shows that oxygen was consumed while $\mathrm{CO}_{2}$ and hydrogen were produced. Neither fluorine nor HF was seen in the gas analyses. The results for the alpha irradiation of $\mathrm{UO}_{2} \mathrm{~F}_{2}$ are in sharp contrast to those seen for gamma irradiation, ${ }^{3,5}$ where oxygen was found to be released from the $\mathrm{UO}_{2} \mathrm{~F}_{2}$ matrix. Therefore, the type of radiation (alpha vs gamma) appears to play a significant role in the net radiolytic effect.

Additionally, as shown in Ref. 3 , the source of some of the hydrogen for moist $\mathrm{UO}_{2} \mathrm{~F}_{2}$ was corrosion of the sample container. In a similar fashion, corrosion may also play some role in the production of hydrogen in the alpha radiolysis experiments.

\subsection{X-RAY DIFFRACTION}

The appearance of $\mathrm{CO}_{2}$ in each of the samples might appear anomalous were it not for the realization that carbon is almost always present in sample preparations and yet goes undetected. When there is a source of oxygen and some means to oxidize the carbon (through elevated temperature or radiolysis), the carbon will combine with the oxygen and appear as $\mathrm{CO}_{2}$. However, the amount of $\mathrm{CO}_{2}$ is insufficient to account for all of the loss of oxygen seen in these experiments. Therefore, another mechanism for oxygen consumption must be present. 
One such mechanism is through the oxidation of the uranium compound itself. Even in the radiation environment, this process would occur at a much slower rate since it is a gas-solid reaction and requires the diffusion of oxygen within the crystalline lattice. In order to establish such a mechanism, the XRD analyses were performed in a effort to identify a higher oxidation state of the uranium itself or an oxidized form of the uranium oxide compound.

Some additional lines were identified as a result of the XRD analysis. These, however, were insufficient to clearly establish oxidation in the current cases. Nevertheless, by comparison of these results with similar observations in the literature, it is apparent that the $\mathrm{U}_{3} \mathrm{O}_{8}$ form is oxidized to $\mathrm{UO}_{3}$ while the $\mathrm{UO}_{3}$ hydrate form is converted to a uranium peroxide. The production of uranium peroxide is most likely to occur in the wet samples where the hydroxyl radical is produced.

The line at $2 \theta$ of 5.48 for the irradiated $\mathrm{U}_{3} \mathrm{O}_{8}$ sample is typical of that for numerous uranyl oxide hydrates, namely the mono- and dihydrates. ${ }^{12-14}$ Except for the line at 17.57, an insufficient number of additional lines exist to clearly identify this new crystalline phase by XRD. However, the data do indicate that the effect of radiation was to generate a new crystalline phase with the major XRD line that is consistent with a uranium oxide of higher oxidation state.

In a similar vein, the appearance of new lines after irradiation of wetted $\mathrm{UO}_{3}$ indicates that it, too, has undergone some phase change as a result of alpha irradiation. In view of the consumption of oxygen (seen from the pressure decrease and gas analyses), we would suggest that some oxidation of the $\mathrm{UO}_{3}$ has also occurred. Higher oxidation states than VI for uranium are not known, but peroxide forms of uranyl such as studtite and metastudtite have been reported in the literature. ${ }^{15-17}$ These particular crystalline materials would have the formulae of $\mathrm{UO}_{3} \cdot \mathrm{H}_{2} \mathrm{O}_{2} \bullet x \mathrm{H}_{2} \mathrm{O}$ (where $x$ is either 2 or 4 , corresponding to metastudtite and studtite, respectively) and are sometimes written as $\mathrm{UO}_{4} \mathrm{GH}_{2} \mathrm{O}$. The most intense lines in the XRD patterns for these studtites would be at $2 \theta$ values (MoK $\alpha$ radiation) of 7.94. Unfortunately, this line would appear on top of the strong line for anhydrous $\mathrm{UO}_{3}$ at 8.03 , thus precluding any firm evidence for the appearance of the peroxide form. However, by comparison with the $\mathrm{U}_{3} \mathrm{O}_{8}$ material, it would be consistent to interpret these results as suggesting that the $\mathrm{UO}_{3}$ has undergone similar oxidation to form a crystalline peroxide species of U(VI).

Such oxidation has already been reported in the literature for much higher alpha irradiation fluxes from a cyclotron. ${ }^{18}$ In this study, a $\mathrm{UO}_{2}$ target in contact with leachant water was irradiated with alpha particles with fluxes up to $3.3 \times 10^{11} \alpha \mathrm{cm}^{-2} \mathrm{~s}^{-1}$. Post-irradiation examination of the $\mathrm{UO}_{2}$ surface that had been in contact with the leachant water revealed the presence of extra lines attributed to metastudtite (i.e., hydrated uranium peroxide). In our case, the alpha flux at the surface of the particles of surface

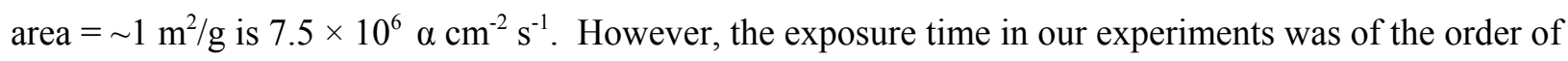
1 year compared with the 1 -h exposure in the previous cyclotron experiment. The overall dose in our experiments is then up to 10 times less than that of the previous work. 
While our results were consistent with those obtained in the previous work, it is not surprising that XRD lines of sufficient intensity were not obtained for definitive conclusions. Nevertheless, the formation of a uranium peroxide in the alpha irradiation of wet $\mathrm{UO}_{3}$ is a plausible explanation for the results obtained. Furthermore, other authors have recently suggested that peroxide, formed by radiolysis, is incorporated into the uranium oxide matrix to form either studtite or metastudtite. ${ }^{19}$

Insufficient data were available to suggest an identity of the phase producing extra lines found as a result of the dry $\mathrm{U}_{3} \mathrm{O}_{8}$ radiolysis experiment. The conversion of the dry $\mathrm{UO}_{3}$ to amorphous material suggests a phenomenon like that seen for other crystalline oxides ${ }^{20}$ exposed to the effects of alpha irradiation. Such a metamict form is yet another possible result of irradiation and probably dependent on the absence of water in the sample.

\subsection{SUMMARY}

The overall mechanism observed in all of these oxide radiolysis experiments is one of several competing reactions. First, nitrate (if present) and water are radiolyzed to some extent at relatively rapid rates. These initial reactions account for the pressure spike in the wet and/or nitrate-containing samples. The water radiolysis, however, reaches a point at which back reactions of the radiolytic products, hydrogen and oxygen, reform the water by well-established radiolytic back-reaction mechanisms. ${ }^{21,22}$ Occurring at a much slower rate is the consumption of oxygen through the uranium oxide oxidation process, producing the oxidized forms identified by other researchers and indicated here.

The alpha radiolysis of uranium oxides can be described in general for wet oxides as a modest pressure rise due to the water radiolysis followed by a net pressure decrease due to the oxidation of the uranium oxide form. If the oxide is dry, no initial pressure rise occurs. Only a steady decrease of the pressure (assuming oxygen is present) is noted as the uranium oxide is further oxidized.

The net result of this overall mechanism is that the pressure over these uranium oxides reaches a steady-state value, where the consumption of the radiolysis products is matched by their production. Except for the case in which there is a high level of residual nitrates, this steady-state pressure is unusually low — and, in many cases, less than the initial pressure of the system. ${ }^{*}$ Furthermore, the concentration of hydrogen is negligible due to its recombination. Consequently, with the occurrence of numerous back reactions, there is no opportunity for the accumulation of hydrogen, or the overall pressure of the system, to build to intolerable limits.

\footnotetext{
* It is evident that efforts to remove nitrates by thermal decomposition are important. The production of $\mathrm{U}_{3} \mathrm{O}_{8}$ at reasonably high temperatures $\left(400-600^{\circ} \mathrm{C}\right)$ will eliminate nitrates.
} 
An interesting comparison can be drawn by considering the maximum hydrogen pressure that could be achieved by radiolyzing all of the available water and the actual measured hydrogen pressure. The former, of course, is the conservative approach taken in storage standards. For example, total decomposition of all available water for sample A-2-1 would result in a hydrogen pressure of about $53,000$ torr ( $\sim 1000 \mathrm{psi})$. The total measured pressure for A-2-1 at steady state was about 4600 torr - $\mathrm{a}$ pressure increase due to nitrogen production (Table 3.2). Significantly, the hydrogen contribution to this pressure was only a small fraction $(\sim 0.24 \%)$ of the total pressure. Similar comparisons can be made for the $\mathrm{U}_{3} \mathrm{O}_{8}(\mathrm{~A}-4-1)$ and $\mathrm{UO}_{2} \mathrm{~F}_{2} \mathrm{Q} \cdot 7 \mathrm{H}_{2} \mathrm{O}(\mathrm{A}-6)$, where total decomposition of the water would result in hydrogen pressures of about 10,000 torr (200 psi) and 45,000 torr ( $870 \mathrm{psi}$ ), respectively. Therefore, it is obvious from the experimental results that high pressures are not reached. In fact, both of these experiments exhibited a net pressure decrease, indicating that back reactions clearly play a strong role in limiting (or eliminating) the pressure increase from radiolysis. 


\section{CONCLUSIONS}

The alpha radiolysis of uranium oxides has shown that several competing reactions are caused by the radioactive environment. These combine to produce pressure changes in closed containers holding these oxides that depend on the constituents in the atmosphere over the oxides and the presence of water or other impurities on the sample. However, none of these reactions produce excessively high pressures as predicted by the pedestrian assumption that any water associated with the samples will be converted entirely to hydrogen and oxygen. Instead, a steady-state pressure is reached at which back reactions quickly limit the accumulation of reaction products in the gas phase. Hydrogen is especially low as a result of radiolysis. Some oxidation of these oxides is possible if oxygen and/or hydroxyl radicals are present. Nevertheless, this oxidation process tends to function as yet another limiting "back reaction" to prevent the occurrence of excessive pressures in the system.

These results, combined with those from the earlier gamma radiolysis experiments, form the basis for resolving technical issues regarding the safe, long-term storage of these oxides and show that extraordinary measures are not required to remove all traces of moisture from the oxide.

\section{ACKNOWLEDGMENTS}

We are grateful to Dr. R. G. Haire of ORNL for the performance of the XRD analysis and his helpful advice. We also acknowledge the highly skilled assistance of C. E. Porter, R. D. Vandergrift, and L. K. Felker in the preparation and conduct of the experiments. 


\section{REFERENCES}

1. Criteria for Preparing and Packaging Plutonium Metals and Oxides for Long-term Storage, DOE-STD-3013, U.S. Department of Energy, Washington, D.C.

2. Criteria for Packaging and Storing Uranium-233-Bearing Materials, DOE-STD-3028-2000, U.S. Department of Energy, Washington, D.C.

3. A. S. Icenhour, L. M. Toth, G. D. Del Cul, and L. F. Miller, "Gamma Radiolysis Studies of Uranyl Fluoride," Radiochim. Acta 90 (2), 109-22 (2002).

4. A. S. Icenhour, L. M. Toth, and H. Luo, Water Sorption and Radiolysis Studies for Uranium Oxides, ORNL/TM-2001/59, Oak Ridge National Laboratory, Oak Ridge, Tennessee, February 2002.

5. A. S. Icenhour and L. M. Toth, A Gamma Radiolysis Study of $\mathrm{UO}_{2} \mathrm{~F}_{2} \cdot 0.4 \mathrm{H}_{2} \mathrm{O}$ Using Spent Nuclear Fuel Elements from the High Flux Isotope Reactor, ORNL/TM-2001/138, Oak Ridge National Laboratory, Oak Ridge, Tennessee, January 2002.

6. R. R. Livingston, Gas Generation Test Support for Transportation and Storage of Plutonium Residue Materials, WSRC-TR-99-00223, Westinghouse Savannah River Company, Savannah River Site, Aiken, South Carolina, August 1999.

7. R. R. Livingston and J. M. Duffey, Effects of Plutonium Dioxide Moisture Content and Calcination Temperature on the Headspace Gas Composition of Sealed Containers, WSRC-TR-2001-00420, Westinghouse Savannah River Company, Savannah River Site, Aiken, South Carolina, September 2001.

8. G. Bailey et al., Gas Generation from Actinide Oxide Materials, LA-13781-MS, Los Alamos National Laboratory, Los Alamos, New Mexico, December 2000.

9. CRC Handbook of Chemistry and Physics, 73rd ed., D. R. Lide, ed., CRC Press, Boca Raton, Florida, 1992.

10. S. Siegel, "The Crystal Structure of Trigonal $\mathrm{U}_{3} \mathrm{O}_{8}$,"Acta Crystallogr. 8, 617-19 (1955).

11. K. Aykan and A. W. Sleight, "Characterization of Mixed Uranium Antimony Oxides $\mathrm{USbO}_{5}$ and $\mathrm{USb}_{3} \mathrm{O}_{10}$ " J. Am. Ceram. Soc. 53, 427-31 (1970). 
12. J. K. Dawson, E. Wait, K. Alcock, and D. R. Chilton, "Some Aspects of the System Uranium Trioxide-Water," J. Chem. Soc. Part III, 3531-40 (1956)

13. C. A. Wamser, J. Belle, E. Bernsohn, and B. Williamson, "The Constitution of the Uranates of Sodium," J. Am. Chem. Soc. 74, 1020-22 (1952).

14. H. Dunn, X-Ray Diffraction Data for Some Uranium Compounds, ORNL-2092, Oak Ridge National Laboratory, Oak Ridge, Tennessee, August 1956

15. K. Walenta, “On Studtite and its Composition,” Am. Mineral., 59, 166-71 (1974).

16. M. Deliens and P. Piret, "Metastudtite, $\mathrm{UO}_{4} \mathrm{CH}_{2} \mathrm{O}$, a New Mineral from Shinkolobwe, Shaba, Zaire," Am. Mineral., 68, 456-58 (1983).

17. P. C. Debets, "X-ray Diffraction Data on Hydrated Uranium Peroxide," J. Inorg. Nucl. Chem., 25, 727-30 (1963).

18. G. Sattonnay et al., "Alpha-radiolysis Effects on $\mathrm{UO}_{2}$ Alteration in Water," J. Nucl. Mater. 288, 11-19 (2001).

19. P. C. Burns and K. Hughes, "Studtite $\left[\left(\mathrm{UO}_{2}\right)\left(\mathrm{O}_{2}\right)\left(\mathrm{H}_{2} \mathrm{O}\right)_{2}\right]\left(\mathrm{H}_{2} \mathrm{O}\right)_{2}$ : The First Structure of a Peroxide Mineral," Am. Mineral, 88, 1165-68 (2003).

20. Hj. Matzke, "Radiation Damage in Crystalline Insulators, Oxides, and Ceramic Nuclear Fuels," Radiat. Eff. 64, 3-33 (1982).

21. C. J. Hochanadel, "Effects of Cobalt Gamma-Radiation on Water and Aqueous Solutions," J. Phys. Chem. 56(5), 587-94 (1952).

22. A. O. Allen, C. J. Hochanadel, J. A. Ghormley, and T. W. Davis, "Decomposition of Water and Aqueous Solutions Under Mixed Fast Neutron and Gamma Radiation," J. Phys. Chem. 56(5), 575-86 (1952). 
ORNL/TM-2003/172

\section{INTERNAL DISTRIBUTION}

1. J. M. Begovich

2. P. J. Bereolos

3. W. D. Bond

4. T. B. Conley

5. G. D. Del Cul

6. D. Foster

7. J. N. Herndon

8. D. J. Hill

9-19. A. S. Icenhour

20. A. M. Krichinsky

21. S. C. Marschman
22. P. E. Osborne

23. F. J. Peretz

24. J. E. Rushton

25. D. W. Simmons

26-30. L. M. Toth

31. L. D. Trowbridge

32. R. M. Wham

33. D. F. Williams

34. ORNL OTIC-RC

35. NSTD DMC

\section{EXTERNAL DISTRIBUTION}

36. N. M. Askew, U.S. Department of Energy, Savannah River Site Operations Office, WSRC, Bldg. 773-A, Road 1A, Aiken, SC 29801

37. L. F. Blankner, U.S. Department of Energy, Oak Ridge Operations Office, Oak Ridge National Laboratory, UT-Battelle, Bethel Valley Road, Oak Ridge, TN 37831-6269

38. H. E. Clark, U.S. Department of Energy, Oak Ridge Operations Office, Oak Ridge National Laboratory, UT-Battelle, Bethel Valley Road, Oak Ridge, TN 37831-6269

39. C. H. Delegard, Pacific Northwest National Laboratory, 902 Battelle Blvd., P.O. Box 999, Richland, WA 99352

40. J. M. Duffey, U.S. Department of Energy, Savannah River Site Operations Office, WSRC, Bldg. 773-A, Road 1A, Aiken, SC 29801

41. P. G. Eller, U.S. Department of Energy, Los Alamos National Laboratory, P.O. Box 1663, Los Alamos, NM 87545

42. H. C. Johnson, U.S. Department of Energy, Headquarters, EM-21, Forrestal Bldg., 1000 Independence Ave. S.W., Washington, D.C. 20585

43. R. R. Livingston, U.S. Department of Energy, Savannah River Site Operations Office, WSRC, Bldg. 773-A, Road 1A, Aiken, SC 29801

44. R. E. Mason, U.S. Department of Energy, Los Alamos National Laboratory, P.O. Box 1663, Los Alamos, NM, 87545

45. L. Morales, U.S. Department of Energy, Los Alamos National Laboratory, P.O. Box 1663, Los Alamos, NM, 87545

46. M. T. Paffett, U.S. Department of Energy, Los Alamos National Laboratory, P.O. Box 1663, Los Alamos, NM, 87545

47. G. D. Roberson, U.S. Department of Energy, Albuquerque Operations Office, Bldg. 382-2, AL, Pennsylvania and H Street, Kirkland Air Force Base, Albuquerque, NM 87116

48. L. A. Worl, U.S. Department of Energy, Los Alamos National Laboratory, P.O. Box 1663, Los Alamos, NM 87545 